\title{
The Global Stratotype Section and Point (GSSP) for the base of the Katian Stage of the Upper Ordovician Series at Black Knob Ridge, Southeastern Oklahoma, USA
}

\author{
1 Department of Geology, University of Dayton, 300 College Park, Dayton, Ohio 45469, USA. Email: dan.goldman@notes.udayton.edu \\ 2 Deparment of Geology and Environmental Science, James Madison University, MSC 6903, Harrisonburg, VA 22807, USA. \\ 3 Institute of Geology at Tallinn University of Technology, Ehitajate tee 5, 19086 Tallinn, Estonia. \\ 4 School of Earth Sciences, Division of Geological Sciences, The Ohio State University, 155 S. Oval Mall, Columbus, Ohio 43210, USA. \\ 5 Department of Geology, University of Cincinnati, Cincinnati, Ohio 45221, USA.
}

The Global Boundary Stratotype Section and Point (GSSP) for the Katian Stage of the Upper Ordovician Series is defined as the 4.0 m-level above the base of the Bigfork Chert in the Black Knob Ridge section, southeastern Oklahoma. This point in this section is coincident with the first appearance of the graptolite Diplacanthograptus caudatus, which has proved to be a reliable datum for precise worldwide correlation. The FAD of D. caudatus occurs very near the first occurrences of the graptolites D. lanceolatus, Corynoides americanus, Orthograptus pageanus, O. quadrimucronatus, Dicranograptus hians, and Neurograptus margaritatus. This rapid succession of fossil species appearance events provides a secure basis for identification of the base of the Katian Stage of the Upper Ordovician Series and for its global chronostratigraphic correlation.

In addition to graptolites, the Black Knob Ridge section also contains biostratigraphically important conodonts and chitinozoans. The conodonts and chitinozoans occur with graptolites on black shale bedding surfaces and allow for the precise correlation of the Katian Stage into regions where the succession is represented by carbonate facies. The base of the Katian Stage occurs high in the Amorphognathus tvaerensis North Atlantic Conodont Zone and just below the base of the Plectodina tenuis North American Midcontinent Conodont Zone. This stratigraphic level is also in close proximity to several important marker horizons - just above the Millbrig and Kinnekulle K-bentonite complexes in eastern North America and Scandinavia, respectively, and just below the beginning of the Upper Ordovician Guttenberg (GICE) $\delta^{13} C$ excursion. These event and chemostratigraphic marker horizons provide an independent test of the global synchroneity of the base of the Katian Stage, and greatly increase the usefulness of that level for global chronostratigraphic correlation.

\section{Introduction}

The International Subcomission on Ordovician Stratigraphy (ISOS) of the International Commission on Stratigraphy (ICS) recently defined the base of the global Upper Ordovician Series to be at the first appearance datum (FAD) of the graptolite species Nemagraptus gracilis in the Fågelsång GSSP in southern Sweden. This designation recognized the tremendous utility for global correlation of the first appearance of a cosmopolitan taxon that occurs within a consistent succession of other first appearance datums (e.g., Finney and Bergström, 1986; Bergström et al., 2000). Current efforts by the ISOS have focused on subdividing the Upper Ordovician into three stages and choosing appropriate levels and stratotypes for the bases of the middle and upper of these stages. The purpose of the present report is to describe the GSSP of the middle stage, for which the name Katian Stage was approved by the ISOS and ratified by the ICS in 2006 (Bergström et al., 2006). For a recent review of the long process of developing the new subdivisions of the Ordovician, see Finney (2005).

\section{Biostratigraphic background}

In the upper part of the range of $N$. gracilis, a new fauna comprising Climacograptus bicornis, members of the Orthograptus calcaratus species group, and a profusion of large dicellograptinids and dicranograptinids appears (Finney and Bergström, 1986). This fauna, commonly referred to as the Climacograptus bicornis Zone fauna, is cosmopolitan and can be precisely correlated within graptolite facies across the world. Unfortunately, the correlation of Upper Ordovician strata above the Climacograptus bicornis Zone is one of the longstanding problems in Ordovician graptolite biostratigraphy. Faunal provincialism has led to the construction of numerous separate zonations, four in North America alone. Establishing detailed correlations between these various zonations has proved difficult and often contentious (e.g., Riva, 1969, 1974; Berry 1970, 1977; Bergström, 1978; Finney, 1986). 
Goldman (2003) noted that one graptolite species, Diplacanthograptus caudatus, is an easily recognizable, cosmopolitan taxon with a consistent FAD within a succession of first appearances of other graptolite taxa, and that the FAD of $D$. caudatus could define the base of a globally recognizable stage boundary that could be correlated with confidence (Figure 1). In most localities, the FAD of $D$. caudatus occurs very near the first occurrences of $D$. lanceolatus, Corynoides americanus, Orthograptus pageanus, O. quadrimucronatus, Dicranograptus hians, and Neurograptus margaritatus. This rapid succession of appearance events following the abrupt demise of the diverse cosmopolitan fauna of the $C$. bicornis Zone provides a secure basis for identification of the base of the $D$. caudatus Zone and for its global chronostratigraphic correlation. Additionally, the FAD of $D$. caudatus is in close proximity to several important marker horizons. It is just above the Millbrig and Kinnekulle K-

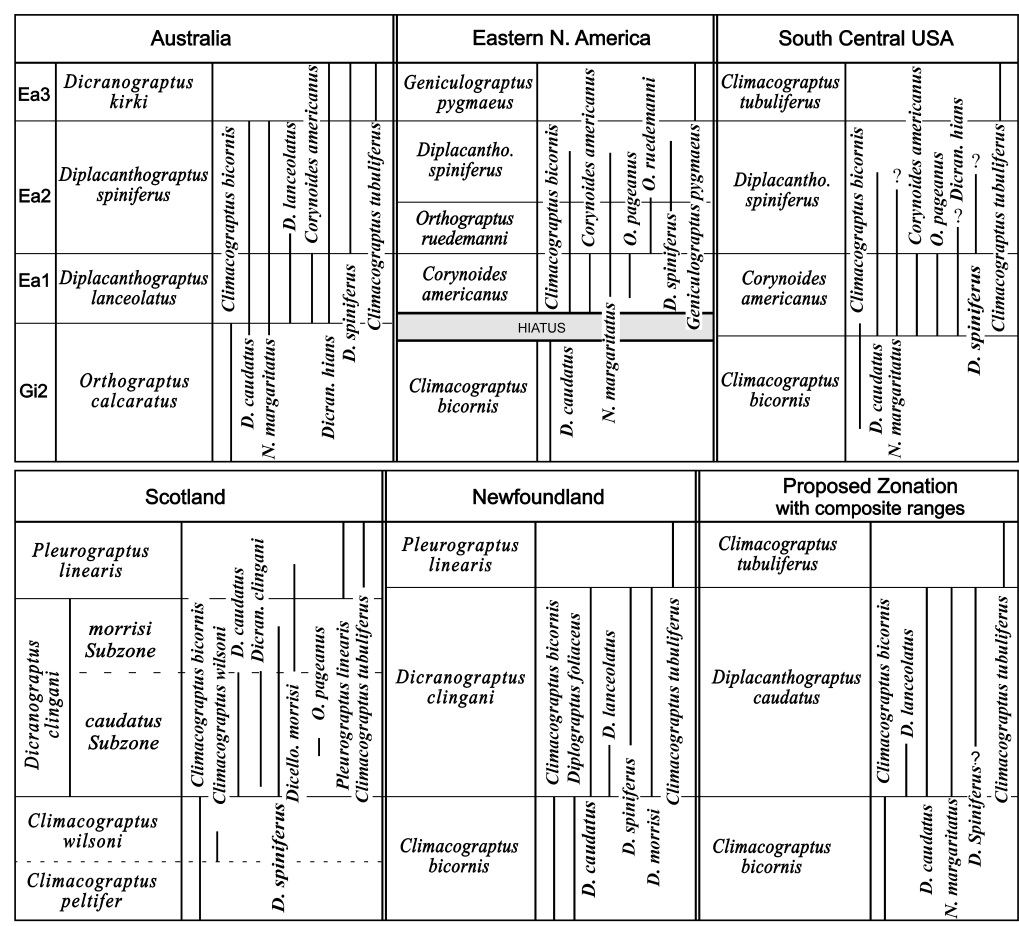

Figure 1 Correlation of post-Nemagraptus gracilis Upper Ordovician graptolite biozones with a comparison of the stratigraphic ranges of some key index species. Data on graptolite ranges from Finney (1986), Goldman et al. (1999), Riva (1969, 1974), VandenBerg and Cooper (1992), Williams (1995), Zalasiewicz et al. (1995), and Chen et al. (2000).

\begin{tabular}{|c|c|c|c|c|c|c|c|c|c|c|c|c|c|}
\hline \multirow{2}{*}{ 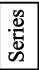 } & \multirow{2}{*}{ 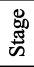 } & \multicolumn{3}{|c|}{$\begin{array}{l}\text { North American Series, Graptolite } \\
\text { Zones and Sequences }\end{array}$} & \multirow{2}{*}{\multicolumn{2}{|c|}{$\begin{array}{l}\text { Australian Stages and } \\
\text { Graptolite Zones }\end{array}$}} & \multirow{2}{*}{\multicolumn{3}{|c|}{$\begin{array}{l}\text { British Series \& } \\
\text { Graptolite Zones }\end{array}$}} & \multirow{2}{*}{$\begin{array}{l}\text { Baltoscandian } \\
\text { Graptolite Zones }\end{array}$} & \multirow{2}{*}{\multicolumn{2}{|c|}{$\begin{array}{l}\text { North Atlantic } \\
\text { Conodont Zones }\end{array}$}} & \multirow{2}{*}{$\begin{array}{c}\text { North American } \\
\text { Midcontinent } \\
\text { Conodont Zones }\end{array}$} \\
\hline & & & Proposed Zones & Eastern N. America & & & & & & & & & \\
\hline \multirow{12}{*}{ 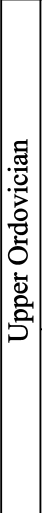 } & \multirow{7}{*}{ 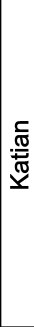 } & \multirow{4}{*}{ 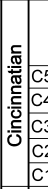 } & $\begin{array}{c}\text { Dicellograptus } \\
\text { complanatus }\end{array}$ & $\begin{array}{l}\text { Dicellograptus } \\
\text { complanatus }\end{array}$ & Bo 1 & $\begin{array}{c}\text { Climacograptus } \\
\text { uncinatus }\end{array}$ & \begin{tabular}{|l|}
$\overline{\bar{D}}$ \\
$\frac{\bar{s}}{\omega}$ \\
\end{tabular} & $\begin{array}{c}\text { Dicel } \\
\text { com }\end{array}$ & $\begin{array}{l}\text { lograptus } \\
\text { planatus }\end{array}$ & $\begin{array}{l}\text { Dicellograptus } \\
\text { complanatus }\end{array}$ & $\begin{array}{c}A m c \\
o\end{array}$ & $\begin{array}{l}\text { rphognathus } \\
\text { rdovicicus }\end{array}$ & A. grandis \\
\hline & & & \multirow{2}{*}{$\begin{array}{l}\text { Climacograptus } \\
\text { tubuliferus }\end{array}$} & $\begin{array}{l}\text { Amplexograptus } \\
\text { manitoulinensis }\end{array}$ & Ea 4 & Dicello. gravis & \multirow{2}{*}{\multicolumn{3}{|c|}{$\begin{array}{l}\text { Pleurograptus } \\
\text { linearis }\end{array}$}} & \multirow{3}{*}{$\begin{array}{l}\text { Pleurograptus } \\
\text { linearis }\end{array}$} & \multirow{5}{*}{\multicolumn{2}{|c|}{$\begin{array}{l}\text { Amorphognathus } \\
\text { superbus }\end{array}$}} & \\
\hline & & & & Geniculograptus & Fo3 & Dicrano & & & & & & & O. velicuspis \\
\hline & & & \multirow{4}{*}{$\begin{array}{c}\text { Diplacanthograptus } \\
\text { caudatus }\end{array}$} & Diplaca & 50 & Diplacan & \multirow{4}{*}{\multicolumn{2}{|c|}{ 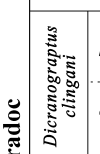 }} & & & & & \\
\hline & & \multirow{3}{*}{$\left.\right|_{\substack{\frac{\pi}{2} \\
\frac{\pi}{2}}} ^{M}$} & & $s p i$ & EdL & 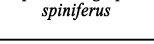 & & & & \multirow{3}{*}{$\begin{array}{l}\text { Dicranograptus } \\
\text { clingani }\end{array}$} & & & s \\
\hline & & & & O. ruedemanni & & & & & & & & & \\
\hline & & & & $\begin{array}{l}\text { Corynoides } \\
\text { americanus }\end{array}$ & Ea1 & & & & & & \multirow{5}{*}{ 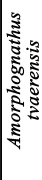 } & \multirow{3}{*}{ alobatus } & P. tenuis \\
\hline & \multirow{5}{*}{ 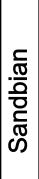 } & \multirow{3}{*}{\begin{tabular}{|l|} 
M \\
$\mathrm{M} 3 \mathrm{M}$ \\
$\mathrm{M} 2$ \\
$\mathrm{M} 1$ \\
\end{tabular}} & \multirow{3}{*}{$\begin{array}{l}\text { Millbrig K-bentonite } \\
\text { Climacograptus } \\
\text { bicornis }\end{array}$} & \multirow{3}{*}{$\begin{array}{c}\text { Diplograptus } \\
\text { foliaceus }\end{array}$} & \multirow{3}{*}{ Gi2 } & \multirow{3}{*}{$\begin{array}{c}\text { Orthograptus } \\
\text { calcaratus }\end{array}$} & \multirow[t]{4}{*}{ שَ } & \multirow{3}{*}{\multicolumn{2}{|c|}{$\begin{array}{c}\text { Climacograptus } \\
\text { wilsoni } \\
\text { Climacograptus } \\
\text { peltifer }\end{array}$}} & \multirow{3}{*}{$\begin{array}{l}\text { Kinnekulle K-bentonite } \\
\text { Diplograptus } \\
\text { foliaceus }\end{array}$} & & & P. undatus \\
\hline & & & & & & & & & & & & & B. compressa \\
\hline & & & & & & & & & & & & B. gerdae & $\begin{array}{l}\text { E. quadridactylus } \\
\text { P. aculeata }\end{array}$ \\
\hline & & & \multirow[t]{2}{*}{$\begin{array}{l}\text { Nemagraptus } \\
\text { gracilis }\end{array}$} & \multirow[t]{2}{*}{$\begin{array}{l}\text { Nemagraptus } \\
\text { gracilis }\end{array}$} & \multirow[t]{2}{*}{ Gi1 } & $\begin{array}{c}\text { Nemagraptus } \\
\text { gracilis }\end{array}$ & & & $\begin{array}{l}\text { nagraptus } \\
\text { racilis }\end{array}$ & $\begin{array}{l}\text { Nemagraptus } \\
\text { gracilis }\end{array}$ & & B. variabilis & C. sweeti \\
\hline & & & & & & & & & & & & dus anserinus & \\
\hline
\end{tabular}

Figure 2 Correlation chart showing proposed chronostratigraphic relations between Upper Ordovician graptolite zones, conodont zones, and important event and chemostratigraphic marker horizons in the principal localities discussed in the text. Modified from Webby et al. (2004). bentonites in Eastern North America and Scandinavia, respectively; just below the base of the Plectodina tenuis Conodont Zone; and just below the beginning of the Upper Ordovician Guttenberg (GICE) $\delta^{13} \mathrm{C}$ excursion (Young et al., 2003, 2005; Figure 2 herein). These events and chemostratigraphic marker horizons provide an independent test on the global synchroneity of the FAD of D. caudatus, and greatly increase its usefulness for chronostratigraphic correlation.

Recently isolated three-dimensionally preserved material of $D$. caudatus (Goldman and Wright, 2003) has clarified the proximal end morphology and phylogenetic relationships of this taxon. Diplacanthograptus caudatus is part of a well-studied sub-clade comprising C. bicornis (Hall), D. lanceolatus (VandenBerg), D. caudatus (Lapworth), D. spiniferus (Ruedemann), and C. tubuliferus Lapworth (VandenBerg, 1990). At the 2003 International Symposium on the Ordovician System in San Juan, Argentina, the Subcommission favored that the base of the second (middle) stage of the Upper Ordovician Series be defined as the FAD of Diplacanthograptus caudatus. Subsequently, after formal voting, the ISOS recommended this level at the Black Knob Ridge section as the GSSP of the Second Stage. After another vote, the ISOS recommended the designation Katian Stage for this stage. These decisions were ratified by the ICS in 2006 (Bergström et al., 2006).

\section{Global Stratotype Section and Point (GSSP)}

\section{Geologic Setting}

The Upper Ordovician rocks exposed in the Ouachita Mountains of west-central Arkansas and southeastern Oklahoma are composed primarily of graptolite-rich dark shales associated with deep-water limestones and cherts (Ethington et al., 1989). These strata were deposited in the deep marine environment off the southern margin of Laurentia (Finney, 1988). The rich graptolite faunas have traditionally been used to correlate these rocks with other Upper Ordovician successions in North America and around the world.

In southeastern Oklahoma Upper Ordovician strata are exposed along Black Knob Ridge, a low narrow ridge at the extreme western end of the Ouachita Mountains (Hendricks et al., 1937; Finney, 1988). The units exposed along Black Knob Ridge are, in ascending order, the Womble Shale, Bigfork Chert, and Polk Creek Shale. The base of the Ordovician succession is in fault contact with the Pennsylvanian Atoka Formation, and the Silurian age Blaylock Sandstone disconformably overlies the top of the sequence (Ethington et al., 1989). An excellent exposure of the Womble Shale to Polk Creek Shale succession is located on the western slope of Black Knob Ridge approximately 5 kilometers north of the town of Atoka, SW1/4, Section 31, T. 1S, R. 12E, Atoka County, Oklahoma; $34^{\circ} 25^{\prime} 39.08^{\prime \prime} \mathrm{N}, 96^{\circ} 04^{\prime} 3.78^{\prime \prime}$ W (Figure 3). This exposure, which we refer to as the Black Knob Ridge (BKR) section, extends along strike for several hundred meters, is readily accessible, contains a continuous graptolite succession across the Climacograptus bicornis Diplacanthograptus caudatus 


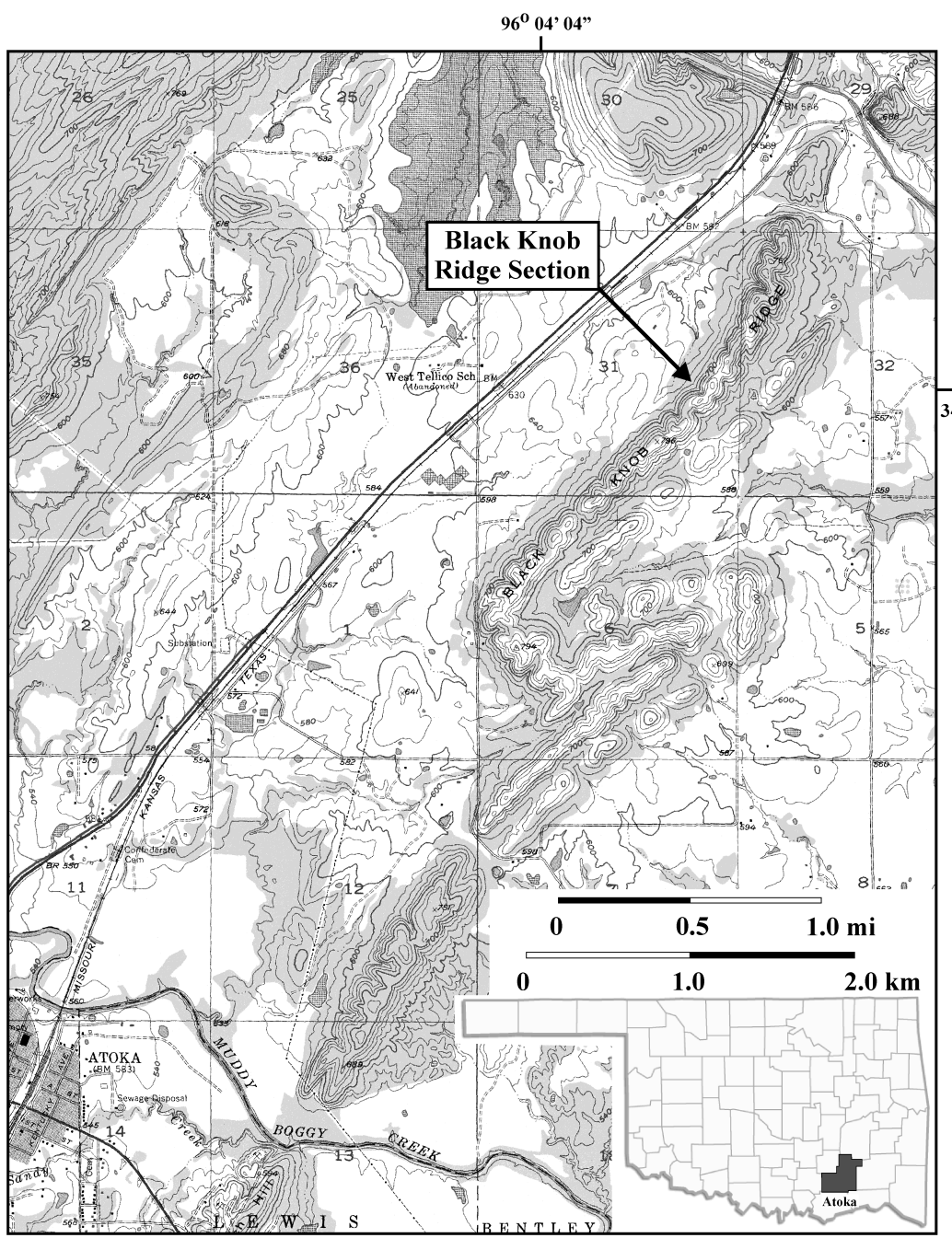

Figure 3 Locality map for the Black Knob Ridge Section. The section is located 5 kilometers north of the town of Atoka, SW1/4, Section 31, T. 1S, R. 12E, Atoka County, Oklahoma; $34^{\circ} 25^{\prime} 39.08^{\prime}{ }^{\prime} \mathrm{N}, 96^{\circ} 04^{\prime} 3.78^{\prime}$ 'W.

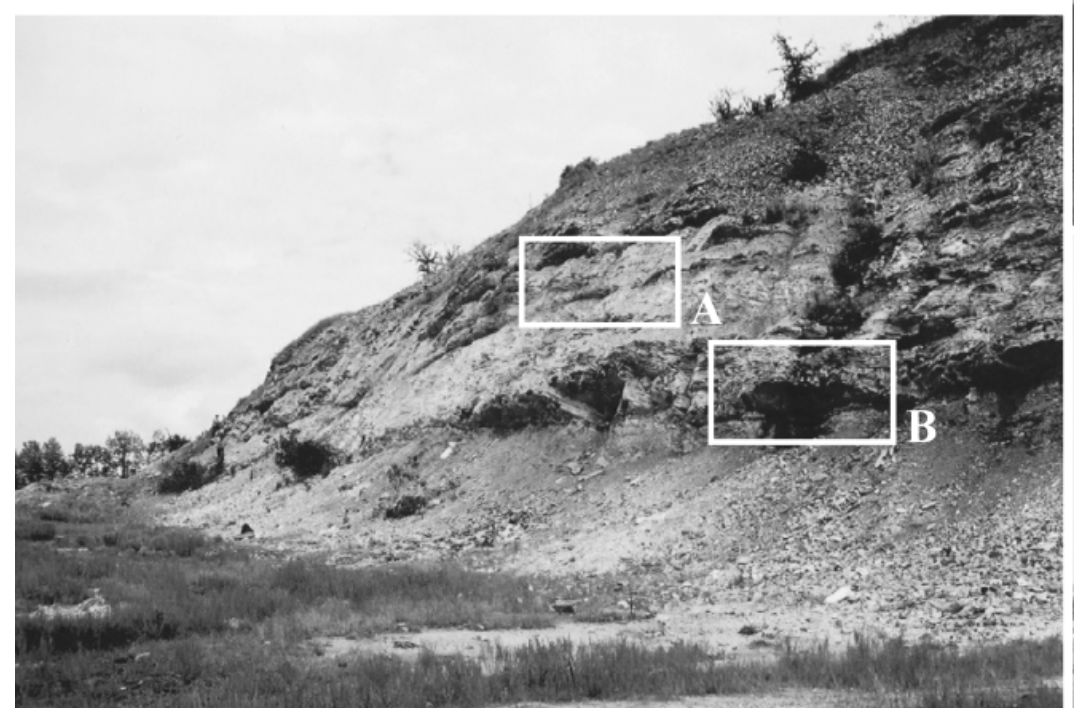

zonal boundary, and yields biostratigraphically important conodonts and chitinozoans.

At the BKR section, approximately 50 meters of black, graptolite-rich Womble Shale are exposed (Figure 4). The upper Womble Shale is composed of soft, tan to chocolate brown-weathering shale and bedded chert. In addition to graptolites, these beds contain conodonts, chitinozoans, sponge spicules, inarticulate brachiopods, and well-rounded quartz sand grains.

Conformably overlying the Womble Shale are approximately 145 meters of Bigfork Chert (Figures 4 and 5). The contact between the two units appears gra${ }^{4^{0} 25}$ '39" dational. The base of the Bigfork Chert is a 0.5 meter interval of hard, splintery black shale that contains abundant conodonts and chitinozoans. The Bigfork Chert is composed of nodular and bedded chert, which is intercalated with black shale and siliceous limestone. Limestone beds are absent in the shale above the Bigfork Chert, and the upper boundary of the Bigfork Chert is placed at the last limestone bed in the section (Finney, 1988). The limestone beds are medium-bedded, siliceous, fine- to coarse-grained skeletal calcarenites. Fossils include graptolites, conodonts, chitinozoans, sponge spicules, radiolarians (Hendricks et al., 1937), pelmatozoans, and brachiopods (Finney, 1988). There is no evidence of a depositional break within the Bigfork Chert at the study section.

The Polk Creek Shale overlies the Bigfork Chert with an apparently conformable contact. Although the thickness of the Polk Creek Shale has not been measured at the BKR section, Hendricks et al., (1937) measured 43 meters at the Atoka city trash dump and Dworian (1990) recorded 32 meters from a locality along Black Knob Ridge south of the proposed stratotype section. The Polk Creek Shale is of pre-Hirnantian age but the Black Knob Ridge succession includes

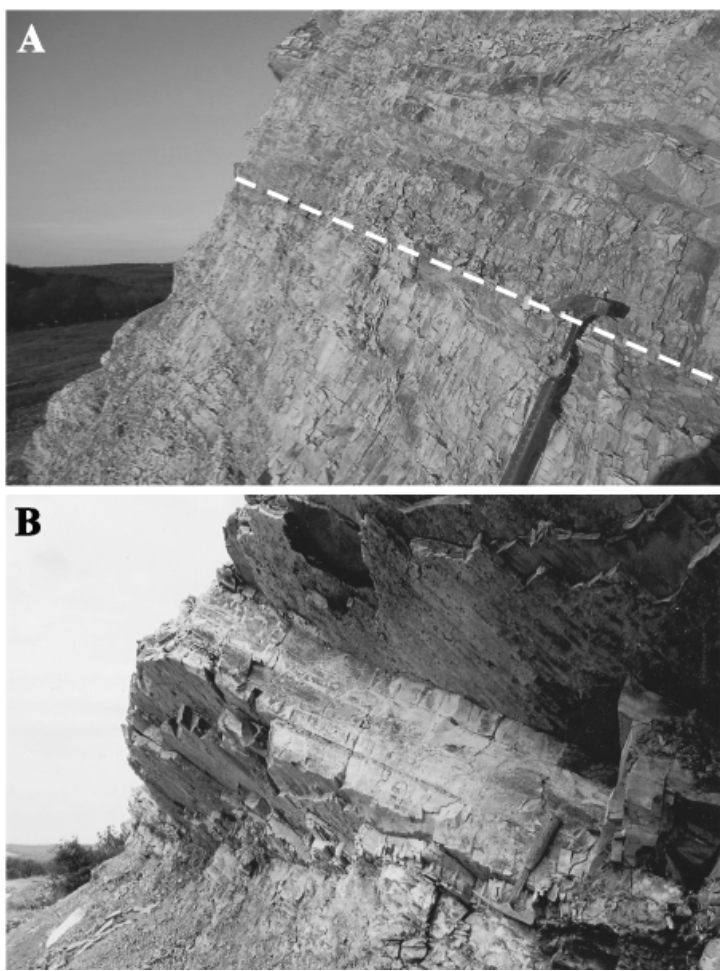

Figure 4 The Black Knob Ridge Section. A) The base of the Diplacanthograptus caudatus Zone. The hammer marks the FAD of D. caudatus. B) The Upper Womble Shale and Bigfork Chert at the Black Knob Ridge Section. The contact between the two units is placed at the first organic-rich, siliceous shale that forms a prominent ledge. This bed is extremely rich in graptolites and conodonts. 


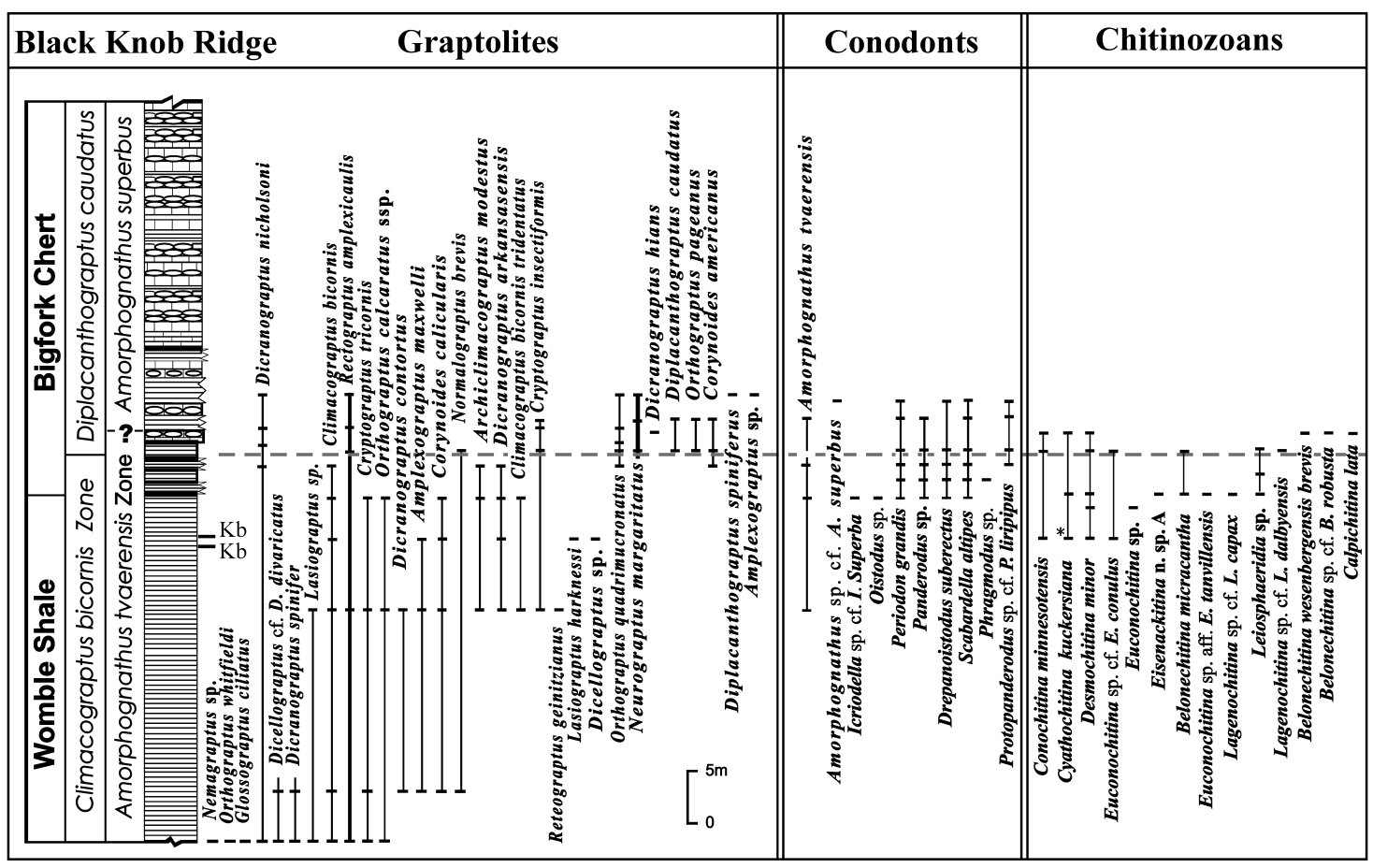

Figure 5 Stratigraphic column with a range chart of graptolites, conodonts, and chitinozoans for the Black Knob Ridge section. Note that the base of the Diplacanthograptus caudatus Zone is placed at the first appearance of D. caudatus four meters above the base of the Bigfork Chert. The $\mathrm{C}$. bicornis - D. caudatus zonal boundary occurs high in the Amorphognatus tvaerensis Conodont Zone.

most of the Katian Stage. For a comprehensive discussion of the geology of these units, see Finney (1986).

\section{Access}

The BKR section is located on the private property of Mr. and Mrs. Doug Howard. Mr. and Mrs. Howard have always allowed access to geologists visiting and studying the section and in a letter signed by Mr. Howard, they have agreed to make the section permanently available to scientific study. The section is reached by driving northeast from Atoka for 5 kilometers on U.S. Route 69, then turning right onto Venta Allen Road, and then making an immediate lefthand turn onto an unpaved road. After approximately 0.5 kilometer, turn right onto the Howard property on an unpaved road that leads directly to the Black Knob Ridge and the GSSP section, which is located just north of a shallow valley that runs across the ridge.

\section{Graptolite biostratigraphy of the GSSP}

Graptolites have been collected and described from the Ordovician rocks of the Ouachita Mountains for over a century (e.g., Gurley, 1892a,b; Ulrich, 1911; Miser and Purdue, 1929; Decker, 1935; Hendricks et al., 1937; Ruedemann, 1908, 1947; Finney, 1986, 1988). Finney $(1986,1988)$ and Ethington et al. (1989) revised the pioneering studies and provided stratigraphic ranges for graptolites in the uppermost Womble Shale and overlying Bigfork Chert from the Stringtown Quarry section at the north end of Black Knob Ridge. Most recently, Goldman et al. (2002) described the graptolite ranges and diversity patterns from the Womble Shale and Bigfork Chert at the GSSP section.

The upper Womble Shale contains an abundant and diverse graptolite fauna that is referable to the Climacograptus bicornis Zone (Figure 5). Diagnostic elements of this fauna include C. bicornis, C. bicornis tridentatus, Orthograptus whitfieldi, O. calcaratus ssp., Archiclimacograptus modestus, Dicranograptus spinifer, D. contortus, D. arkansasensis, Normalograptus brevis, and Nemagraptus gracilis. The transition between the $C$. bicornis Zone and the underlying $N$. gracilis Zone has not yet been found at Black Knob Ridge.

Climacograptus bicornis, C. bicornis tridentatus, Archiclimacograptus modestus, and Dicranograptus arkansasensis range upward into the lowermost 3.1 meters of the Bigfork Chert. Orthograptus quadrimucronatus makes its first appearance 3.2 meters above the base of the Bigfork Chert. The base of the Katian Stage is placed at the FAD of Diplacanthograptus caudatus, 4.0 meters above the base of the Bigfork Chert (Figure 5). At this horizon, several taxa diagnostic of the D. caudatus Zone first appear (Figure 6). These are $D$. caudatus, Orthograptus pageanus, Neurograptus margaritatus, and Corynoides americanus. Dicranograptus hians was found 2.0 meters higher up. Diplacanthograptus spiniferus and Climacograptus tubuliferus debut at 9.8 and 52.5 meters, respectively, above the base of the Bigfork Chert (Finney, 1986 and personal communication).

There is no evidence of a hiatus or sedimentological discontinuity in the C. bicornis - D. caudatus boundary interval. Less than 1 meter $(0.9 \mathrm{~m})$ separates the uppermost collection of $C$. bicornis Zone graptolites from the FAD of D. caudatus. This $0.9 \mathrm{~m}$ interval is characterized by thickly bedded chert and siliceous limestone, and no identifiable graptolites were found in this interval despite an intensive search. Thus, the boundary interval at Black Knob Ridge is graptolite-rich and contains a very well defined base of the D. caudatus Zone.

\section{Conodont biostratigraphy of the GSSP}

Conodonts have been known from the Black Knob Ridge since Hendricks et al.'s (1937) description of the geology at Black Knob Ridge. Harlton (1953) also reported the occurrence of conodonts at this locality. However, as Repetski and Ethington (1977) and Ethington et al. (1989) reported, these early studies did not identify the conodonts, and their stratigraphic occurrences were not adequately documented. Bradshaw (1974) identified a conodont fauna of Midcontinent aspect from the Bigfork Chert at BKR. She reported occurrences to the genus-level, and identified representatives of Panderodus, Belodina, Drepanodus, Oistodus, and Phragmodus from siliceous limestone beds. More recently, Krueger (2002) reported on the occurrence of a similar Midcontinent conodont fauna in limestone beds in the Stringtown Quarry approximately 3 kilometers north of the GSSP section.

Recently, we collected shale samples for conodont study across the Womble Shale-Bigfork Chert boundary at the GSSP. Detailed study of these led to the discovery that there are well-preserved conodonts on the shale bedding planes in both the Womble Shale and Bigfork Chert that are typical of the North Atlantic Fauna. The limestone beds in the lower part of the Bigfork Chert at the GSSP section 

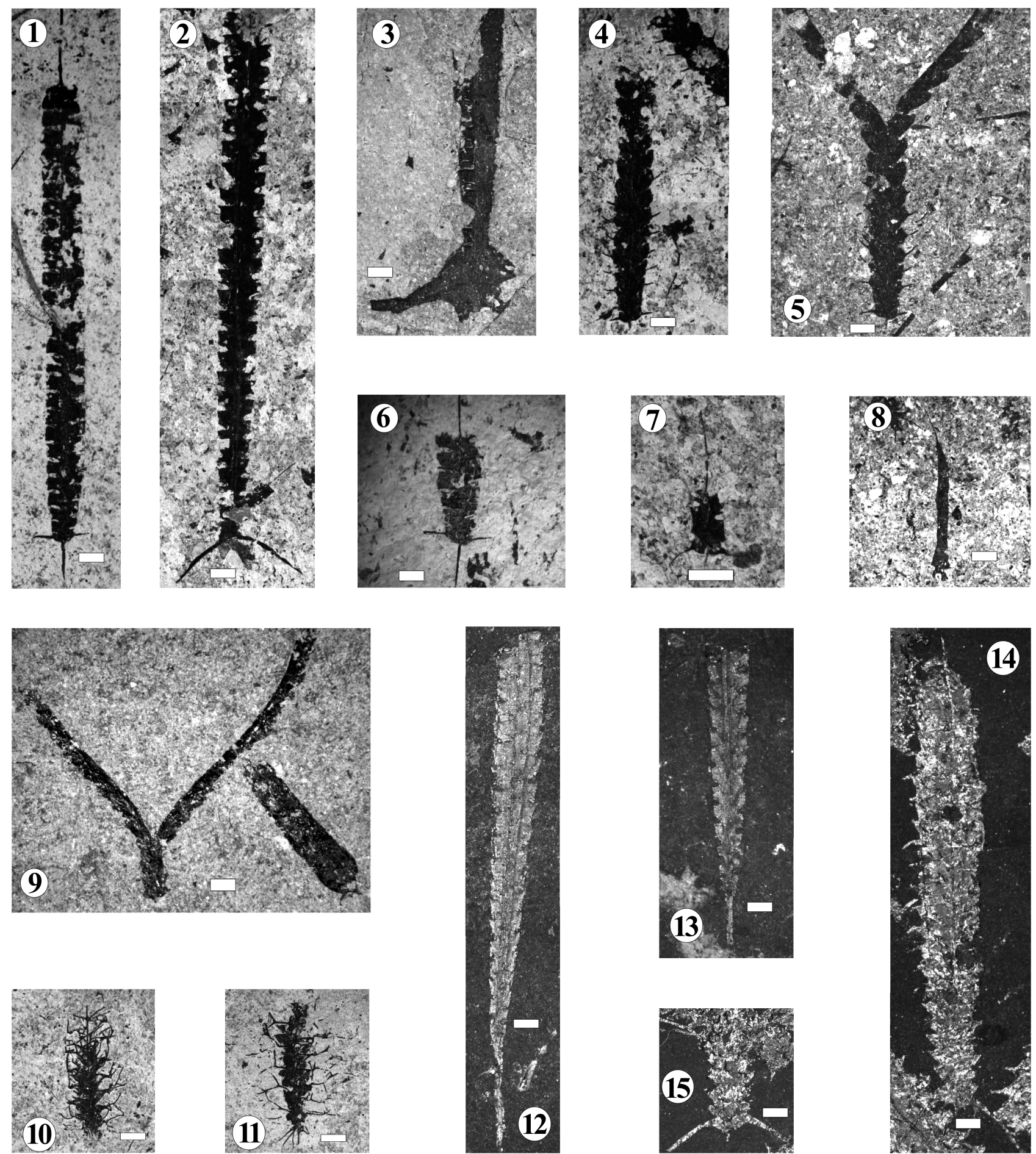

Figure 6 Graptolites from Black Knob Ridge. 1-8, graptolites from the Climacograptus bicornis Zone. 1, 6 Archiclimacograptus modestus. 2, 3, 7 Climacograptus bicornis. 4, 5 Dicranograptus spinifer (= D. nicholsoni longibasalis). 8 Corynoides calicularis. 9-15 graptolites from the Diplacanthograptus caudatus Zone. 9 Dicranograptus hians and Cryptograptus insectiformis. 10, 11 Neurograptus margaritatus. 12, 13 Diplacanthograptus caudatus. 14, 15 Orthograptus pageanus. Scale bar on each photograph is $1 \mathrm{~mm}$.

are completely silicified and, therefore, have not been dissolved for conodonts.

The uppermost Womble Shale contains an abundant, low diversity conodont fauna with biostratigraphically important species, such as elements of Amorphognathus tvaerensis and Icriodella cf. I. superba. The co-occurrence of I. cf. I. superba and A. tvaerensis demonstrates that the uppermost Womble Shale at the GSSP is probably within the B. alobatus Subzone of the A.tvaerensis Zone, which is the uppermost part of the A. tvaerensis Zone (Bergström, 1982).
The previously reported youngest conodont fauna from the Womble Shale (Repetski and Ethington, 1977; Ethington et al., 1989) is from a different locality and represents the $B$. gerdae Subzone of the $A$. tvaerensis Zone, which is the subzone below the B. alobatus Subzone. The uppermost Womble Shale at the GSSP also contains Periodon grandis, Drepanoistodus suberectus, Scabbardella altipes, Oistodus sp. and Panderodus sp. (Figures 5 and 7).

The conodont fauna from lowermost Bigfork Chert at the GSSP consists of A. tvaerensis, Periodon grandis, Protopanderodus cf. $P$. 

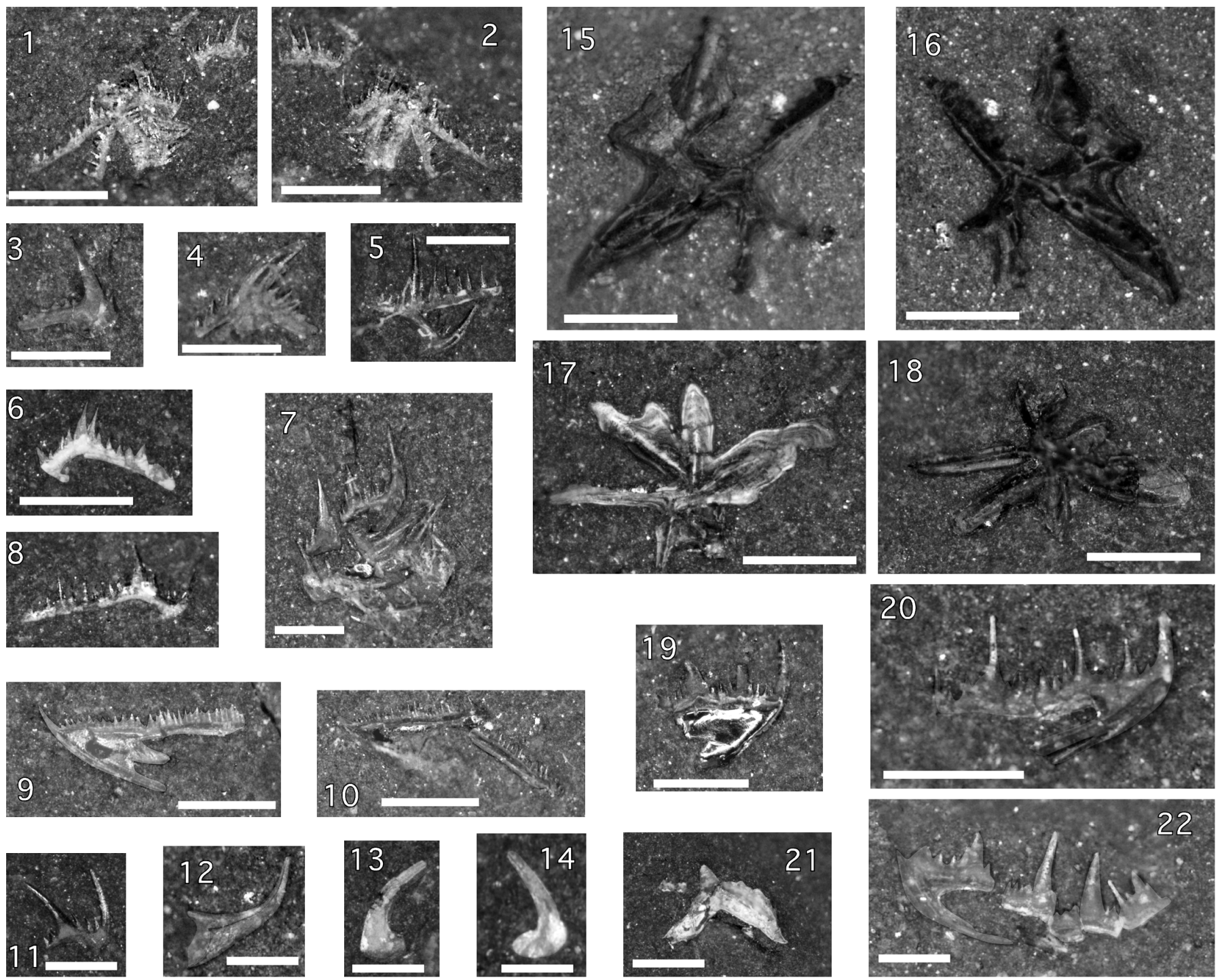

Figure 7 Conodonts from Black Knob Ridge. Scale bar in all images is $0.5 \mathrm{~mm} .1$-2 part and counterpart of a Periodon grandis bedding plane association 0.3 meters below the top of the Womble Shale, 3-8 Periodon grandis 0.3 meters below the top of the Womble Shale. 9-10 Icriodella $\mathrm{cf}$. I. superba 0.3 meters below the top of the Womble Shale. 11 Phragmodus sp. from base of Bigfork Chert, 12 Scabbardella altipes from 0.3 meters below the top of the Womble Shale, 13-14, Drepanoistodus suberectus 0.3 meters below the top of the Womble Shale. 15-16, Amorphognathus sp. $5.7 \mathrm{~m}$ above the base of the Bigfork Chert. Note the absence of the accessory posterior lobe. This suggests that 15 and 16 may be A. superbus. Additional collecting is needed to verify this interpretation. 17-22 Amorphognathus tvaerensis from 0.3 meters below the top of the Womble Shale

liripipus, Drepanoistodus suberectus, Scabbardella altipes, Phragmodus sp., and Panderodus sp. This fauna is nearly identical to the fauna from the upper Womble Shale, with the exception of the presence of relatively abundant specimens of $P$. cf. $P$. liripipus. Of interest is the occurrence of two specimens of Amorphognathus sp. cf. A. superbus at a level approximately 5.7 meters above the base of the Bigfork Chert (Figure 7). These specimens are morphologically similar to A. superbus, however unquestionable identification is not possible based on the material at hand.

The biostratigraphically significant conodonts known from the GSSP suggest that the Climacograptus bicornis - Diplacanthograptus caudatus zonal boundary is located in the B. alobatus Subzone of the Amorphognathus tvaerensis Conodont Zone. This correlation is consistent with the graptolite - conodont zonal relationships described from Europe and eastern North America by Bergström (1971, 1986) and Goldman et al. (1994). Further collecting will undoubtedly result in a more precise conodont biostratigraphy and an increased resolution in the correlation between the conodont and graptolite zones at this site.

\section{Chitinozoan biostratigraphy of the GSSP}

Upper Ordovician chitinozoans of Oklahoma have been described by Grahn and Miller (1986) from the Bromide Formation and by Jenkins (1969) from the Viola Springs Formation. These studies were based on samples collected in the carbonate facies of the Arbuckle Mountains. Chitinozoans have been previously noted but not described from weathered shale surfaces in the Womble Shale and Bigfork Chert at Black Knob Ridge (Finney, 1988). Flattened chitinozoans are abundant and visible on the weathered surfaces of the organic-rich shale beds that also contain our conodont samples. Additionally, hydrofluoric acid dissolution of shale beds across the $C$. bicornis - D. caudatus zonal boundary has yielded a low diversity, poorly preserved, but biostratigraphically significant, chitinozoan fauna (Figure 8).

Our lowermost sample, 4 meters below the Bigfork Chert, contained Conochitina minnesotensis, Cyathochitina $\mathrm{cf}$. C. kuckersiana, Desmochitina minor, and Euconochitina cf. E. conulus. A sample 1.0 meter below the Bigfork Chert yielded Desmochitina minor and Euconochitina sp., and the uppermost Womble Shale sample, 0.1 

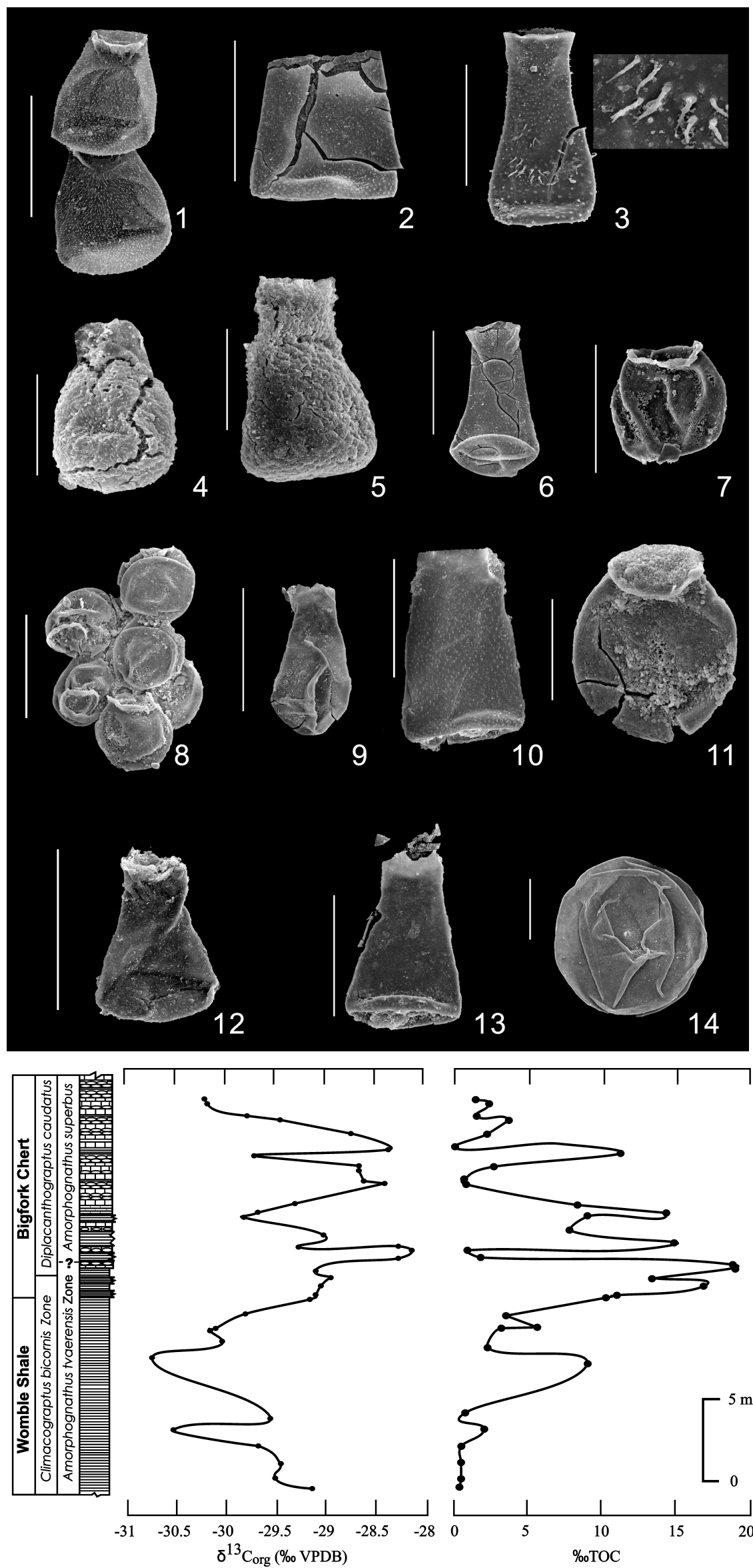

Figure $9 \delta^{13} C$ and \%o total organic carbon data obtained from shale horizons across the boundary interval at Black Knob Ridge.
Figure 8 Chitinozoans from Black Knob Ridge. Scale bar is $0.1 \mathrm{~mm}$, except figs. 4, 5, and 11, where the bar is $0.05 \mathrm{~mm}$. Figures 1-8, 14: Womble Shale, $0.1 \mathrm{~m}$ below the base of the Big Fork Chert. 1 Eisenackitina sp. A. 2 Belonechitina micracantha (Eisenack) [broken specimen]. 3 Belonechitina sp. A. 4 Lagenochitina $c f$. L. capax Jenkins [filled with pyrite]. 5 Euconochitina aff. E. tanvillensis (Paris) [filled with pyrite]. 6 Euconochitina aff. E. tanvillensis (Paris). 7-8 Desmochitina minor Eisenack, s.l. 14 Prasinophycean algae Leiosphaeridia sp. Figures 9-13 Big Fork Chert, sample about $4 \mathrm{~m}$ above of its base. 9 Lagenochitina aff. L. dalbyensis (Laufeld). 10 Belonechitina micracantha (Eisenack). 11 Desmochitina minor Eisenack. 12-13 Euconochitina $c f$. E. conulus (Eisenack).

meter below the Bigfork Chert, contained Eisenackitina sp., Belonechitina micracantha, Cyathochitina kuckersiana, Euconochitina aff. E. tanvillensis, Desmochitina minor, Lagenochitina cf. L. capax, Belonechitina n. sp. A, and the prasinophycean achritarch Leiosphaeridia sp. Samples 2 meters above the base of the Bigfork Chert contained Leiosphaeridia sp.; those at the base of the D. caudatus Zone (4 meters above the base of the Bigfork Chert) had Conochitina minnesotensis, Belonechitina micracantha, Cyathochitina sp., Desmochitina minor, Lagenochitina aff. L. dalbyensis, Euconochitina cf. E. conulus, and Leiosphaeridia sp.; and our uppermost sample at 6 meters yielded Belonechitina wesenbergensis brevis, Belonechitina cf. B. robusta, Calpichitina lata, Cyathochitina kuckersiana, Desmochitina minor and unidentifiable conical forms (Figure 8)

Because of the poor preservation of the isolated specimens (see Figure 8), they are difficult to identify with confidence. However, the chitinozoan fauna from the boundary interval at Black Knob Ridge does show a broad similarity to Baltoscandian faunas from the Haljala to Keila stages (time slices $5 b$ and $5 c$ of Webby, et al., 2004; and see Nõlvak and Grahn, 1993, and Paris, 1990). This agrees well with the graptolite and conodont data and further work should produce a more refined chitinozoan biostratigraphy.

\section{Event and chemostratigraphy of the GSSP}

The GSSP section has recently been sampled for organic $\delta^{13} \mathrm{C}$ study. There is an interesting trend toward higher $\delta^{13} \mathrm{C}$ values (a $+2.5 \%$ excursion) just above the boundary interval (Figure 9 herein; Leslie et al., 2004). This trend occurs in a similar stratigraphic position as the GICE $\delta^{13} \mathrm{C}$ excursion (Patzkowsky et al., 1997; Young et al., 2003, 2005). However, whereas at most other localities the GICE $\delta^{13} \mathrm{C}$ excursion has been based on carbonate carbon in limestones, the $\delta^{13} \mathrm{C}$ data obtained at Black Knob Ridge are from organic carbon in the shale. Further work is necessary to confirm that the observed trend at the GSSP indeed represents the GICE $\delta^{13} \mathrm{C}$ excursion and additional samples are currently being analyzed. 


\section{K-bentonites of the GSSP}

Recent work at Black Knob Ridge has also resulted in the discovery of K-bentonite beds, and clay beds that may prove to be Kbentonite beds, in both the upper Womble Shale and the lower Bigfork Chert (Leslie et al., 2006). As described in Leslie et al. (in press), one K-bentonite, 4 centimeters thick, occurs 4.3 meters below the top of the Womble Shale and another such bed is present 0.7 meters below this bed. Five thin clay beds have been found in the 5.8-7.3 meters interval below the base of the Bigfork Chert but their possible K-bentonite nature has not yet been investigated. There are also three thin clay beds at $6.4,6.5$, and 6.8 meters, respectively above the base of the Bigfork Chert but also these beds have not yet been subjected to geochemical study. However, all these beds have the potential to contain minerals useful for radiometric datings of horizons close to the base of the Katian Stage at the GSSP. As will be discussed further below, they occur in the same biostratigraphic interval as the widespread Deicke and Millbrig K-bentonites and chemical fingerprinting may clarify whether or not any of the K-bentonite beds at the GSSP may represent these gigantic ash falls.

\section{Supplemental Section}

Upper Ordovician rocks are excellently exposed in the Arbuckle Mountains of south-central Oklahoma about 60 kilometers west of Black Knob Ridge. These strata were deposited within, and on, the platform bordering the Southern Oklahoma Aulacogen and represent a shallower depositional environment than the deep-water shale, chert, and limestone of the Ouachita Mountains (Finney, 1986, 1988). During the Late Paleozoic the Ouachita strata were thrusted

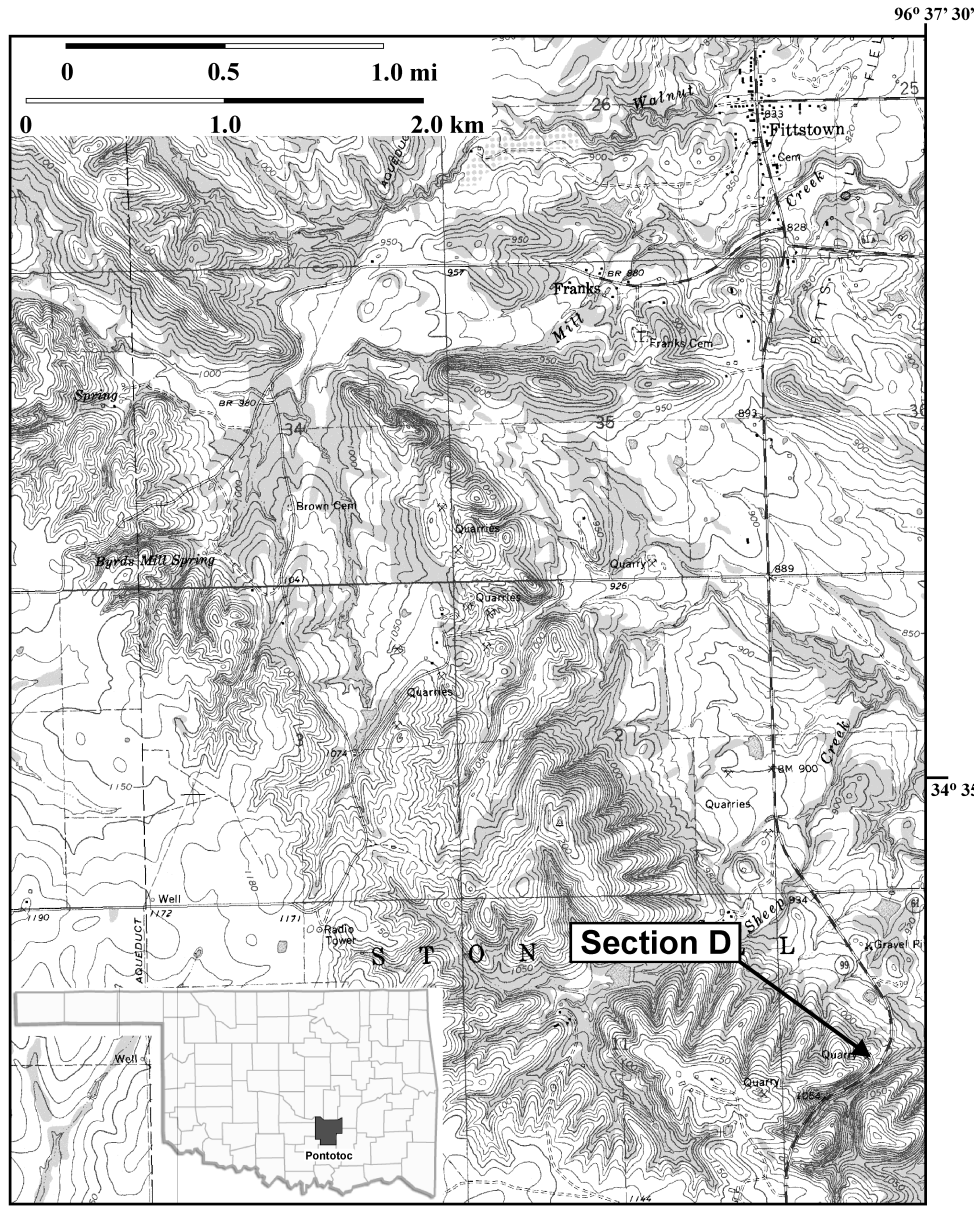

Figure 10 Locality map for supplemental section, Section D. The locality is $5.5 \mathrm{~km}$ south of Fittstown, Oklahoma (NW1/2 SW1/4 sec. 12, T. 1N, R. 6E, Pontotoc County). cratonward leaving the distinctly different facies of the Ouachita and Arbuckle Mountains juxtaposed geographically (Finney, 1988). The GSSP section can, however, be correlated into the carbonate-rich facies of the Arbuckle Mountains using graptolite and conodont biostratigraphy. Thus, the GSSP section, which contains a fauna dominated by graptolites, can be correlated with nearby carbonatedominated sections that contain a more complete conodont species succession and are part of Sweet's $(1979,1984,1995)$ graphic correlation framework.

The Upper Ordovician limestones of the Arbuckle Mountains include the Bromide, Viola Springs, and Welling formations, in ascending order. The Viola Springs and Welling formations, which together comprise the Viola Group, are well known for yielding three-dimensionally preserved graptolites (e.g., Finney, 1986). One outcrop along the west side of U.S. Highway 99 approximately 5.5 $\mathrm{km}$ south of Fittstown, Pontotoc County contains a graptolite succession that is nearly identical (although much less complete) to that of the GSSP section. This locality (NW1/2 SW1/4 sec. 12, T. 1N, R. $6 \mathrm{E})$ has been described by, among others, Alberstadt (1973, Section D), Finney $(1986,1988)$, and Sweet (1983), and it is herein referred to as Section D (Figure 10).

\section{Graptolite biostratigraphy of Section D}

The lower 0.5 meters of the Viola Springs Formation at Section D consists of siliceous laminated calcareous mudstones (Unit 1, subunit 1L of Alberstadt, 1973) that contain abundant graptolites of the Climacograptus bicornis Zone. Our collections include $C$. bicornis, Dicranograptus spinifer $(=D$. nicholsoni longibasalis Ruedemann and Decker), Rectograptus n. sp., and Corynoides calicularis. A horizon 5 centimeters higher yielded Orthograptus quadrimucronatus and Lasiograptus harknessi in addition to the previously mentioned species (Figure 11). The presence of O. quadrimucronatus indicates that this collection represents the uppermost part of the $C$. bicornis Zone.

Above the 0.55 meters-level the lithology changes to skeletal calcisiltites and calcarenites with nodular and bedded chert (Unit 1, subunit 1C of Alberstadt, 1973). This lithofacies dominates the section for the next 40 meters stratigraphic interval and the beds are nearly devoid of graptolites. Finney (1986) reported the presence of $D$. spiniferus at 35 meters above the base of the Viola Springs at Section D, and we collected Diplacanthograptus caudatus, Cryptograptus insectiformis, Corynoides sp., and Orthograptus sp. at the 43 meters-level. Collections from the 51 meters level contain Diplacanthograptus caudatus, Geniculograptus typicalis, and Orthoretiolites hami. The large stratigraphic gaps between the graptolite collections and the truncation of the base of the range of D. caudatus indicate that Section D is not suitable as a stratotype section. It is best used as a supplemental section that facilitates correlation of the D. caudatus Zone into a shallower water conodont biofacies.

Our graptolite information indicates that the contact between Bromide Formation and the overlying Viola Springs Formation is very similar in age to the Womble Shale - Bigfork Chert contact at Black Knob Ridge and this agrees with the correlations proposed by Finney (1988). In the GSSP section, Climacograptus bicornis Zone graptolites range up into the lowermost part of the Bigfork Chert. The base of the Diplacanthograptus caudatus Zone occurs 4 meters above the base of the Bigfork Chert, and is within the uppermost part of the Amorphognathus tvaerensis North Atlantic conodont Zone. At Section D, Climacograptus bicornis Zone graptolites occur in the lowermost 0.55 meters of the Viola Springs Formation. The FAD of $O$. quadrimucronatus at 0.55 meters indicates that these beds represent the very top of the $C$. bicornis Zone. The horizon at Section D that is synchronous with the base of the Diplacanthograptus caudatus Zone at the GSSP likely lies in an interval devoid of graptolites. However, the conodonts at Section D provide good biostratigraphic control. 


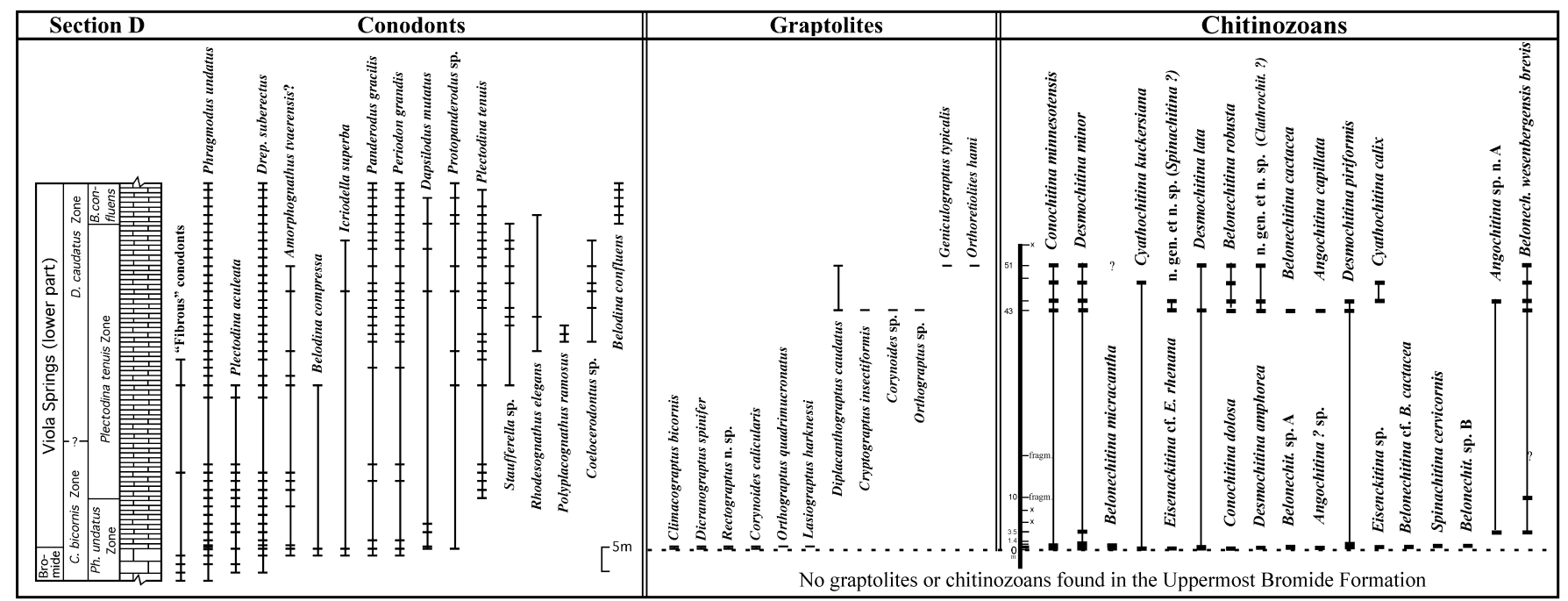

Figure 11 Stratigraphic column with a range chart of graptolites, conodonts, and chitinozoans for Section D. See text for explanation.

\section{Conodont biostratigraphy of Section D}

Sweet (1983) presented a detailed conodont biostratigraphy of Section D. He used Oberg's (1966) conodont samples from the Viola Springs Formation, and added to those collections four samples from the underlying Corbin Ranch Submember of the Pooleville Member of the Bromide Formation. Section D is part of Sweet's $(1983,1984,1995)$ graphically correlated sections, allowing correlation of this section with many other sections by means of conodont graphic correlation.

The lowermost part of the Viola Springs Formation contains a typical $P$. undatus Zone fauna that is dominantly of Midcontinent faunal aspect containing P. undatus, Plectodina aculeata, and Belodina compressa. Additionally, there are species that are more typical of the North Atlantic Province such as Icriodella superba, Periodon grandis, and Amorphognathus tvaerensis?. These species are the dominant members of the North Atlantic Faunal Province species present in the upper Womble and lower Bigfork at the GSSP.

The $P$. undatus Zone fauna is followed by a $P$. tenuis Zone fauna that contains not only the zonal indicator $P$. tenuis, but also includes the biostratigraphically important taxa Polyplacognathus ramosus and Rhodesognathus elegans. These species occur in samples below the first appearance of $D$. caudatus. At approximately 58.5 meters above the base of the Viola Springs Formation is the first occurrence of Belodina confluens, the index of the B. confluens Zone. This sequence of first appearance datums of zonal indicator species along with additional biostratigraphically important species makes Section D a valuable supplemental section. In addition, the more cosmopolitan and long-ranging species Dapsilodus cf. D. mutatus, Panderodus sp., and Drepanoistodus suberectus are present at both Section D and the GSSP.

\section{Chitinozoan biostratigraphy of Section D}

The Viola Springs Formation at Section D also contains a diverse and well-preserved chitinozoan fauna. Nineteen limestone samples (approximately 0.3 to $0.4 \mathrm{~kg}$ in weight) from the upper Bromide and Viola Springs formations were processed for chitinozoans. The lagoonal "bird's-eye" facies of the Upper Bromide contained no chitinozoans, nor did samples of Viola Springs Formation between the 5 and 43 meters levels (see Figure 11). This latter interval was also almost barren for graptolites, which we interpret as indicating the results of diagenetic processes that destroyed organic-walled fossils. Previous studies of chitinozoans from the Arbuckle Mountains of Oklahoma have documented older chitinozoan assemblages from the Bromide Formation (Grahn and Miller, 1986) and younger assemblages from the Viola Springs Formation at Sycamore Creek
(Jenkins, 1969). This is the first report of chitinozoan faunas that span the age gap between these two earlier chitinozoan assemblages.

Rich chitinozoan assemblages appear just above the top of the Bromide Formation in a 5 to 10 centimeters thick detritus-rich limestone that marks the base of the Viola Springs Formation, and in the interval of 43 to 51 meters above the base of the latter formation (Figures 12 and 13). These samples yielded hundreds to thousands of well-preserved specimens. The lower productive interval, between 0 and 1.4 meters above the base of the Viola Springs Formation, contained Conochitina minnesotensis, Desmochitina minor, Belonechitina micracantha, Pistillachitina sp., Cyathochitina kuckersiana, Eisenackitina aff. E. rhenana, Belonechitina n. sp. C, Calpichitina lata, Conochitina tigrina, Conochitina dolosa, Spinachitina cervicornis, Desmochitina amphorea, Belonechitina n. sp. A, Desmochitina cf. D. piriformis, Belonechitina $\mathrm{cf}$. B. cactacea, Spinachitina alaticornis, Belonechitina n. sp. B, Belonechitina wesenbergensis brevis, and Angochitina n. sp. A.

This fauna contains several biostratigraphically important taxa that have short vertical ranges in Baltoscandia. The presence of Spinachitina cervicornis, and the fact that Desmochitina amphorea, Conochitina dolosa, and Conochitina tigrina do not range above the lower Keila Stage in Baltoscandia (Nõlvak and Grahn, 1993) indicates that the lowermost Viola Springs Formation at Section D belongs to $S$. cervicornis chitinozoan Zone and is no younger than the early Keila Stage. This is in complete agreement with the graptolite and conodont biostratigraphy (upper C. bicornis Graptolite Zone and the Phragmodus undatus Conodont Zone).

The upper productive interval contains Conochitina minnesotensis, Desmochitina minor, Desmochitina cf. D. piriformis, Cyathochitina kuckersiana, C. calix, Belonechitina cactacea, B. robusta s.l., B. wesenbergensis brevis, Calpichitina lata, Spinachitina? n. sp. A, Clathrochitina? n. sp., Angochitina capillata, and Angochitina n. sp. A. These chitinozoans suggest that the base of Diplacanthograptus caudatus Zone correlates with the middle of the Keila Stage in the Baltoscandian succession (lower part of time slice $5 \mathrm{c}$ of Webby et al., 2004). Further work is still needed, however, to clarify the exact position of the FAD of D. caudatus with respect to the Baltoscandian chitinozoan zonation.

\section{Event and chemostratigraphy of Section D.}

The GICE $\delta^{13} \mathrm{C}$ excursion has also been reported from Section D. Young et al. (2005) noted that this $\delta^{13} \mathrm{C}$ excursion starts just above the base of the P. tenuis Conodont Zone. As noted above, samples for carbon isotope analysis have recently been analyzed also from the GSSP section and, pending corroboration, they seem to pro- 
vide an independent confirmation of our graptolite and conodont correlations.

The lithologically striking change from the Bromide Formation to the Viola Springs Formation marks an important unconformity in the Arbuckle Mountains. In the central Arbuckle Mountains sections, such as those along I-35, this unconformity represents a very significant stratigraphic gap as indicated by both graptolite and condont biostratigraphy (Finney, 1986). This gap, although present, is of smaller magnitude at the $\mathrm{D}$ section, where it is restricted to a part of the C. bicornis Graptolite Zone and the P. undatus Conodont Zone. It obviously represents a sequence boundary and Young et al. (2005) suggested that it is equivalent to the M4/M5 sequence boundary recognized in Kentucky and adjacent states (Holland and Patzkowsky, 1996). It may well be that the contact between the Womble Shale and the Bigfort Chert corresponds to that sequence boundary (Leslie et al., in press) although the stratigraphic gap, if present, is likely to quite small at the GSSP.

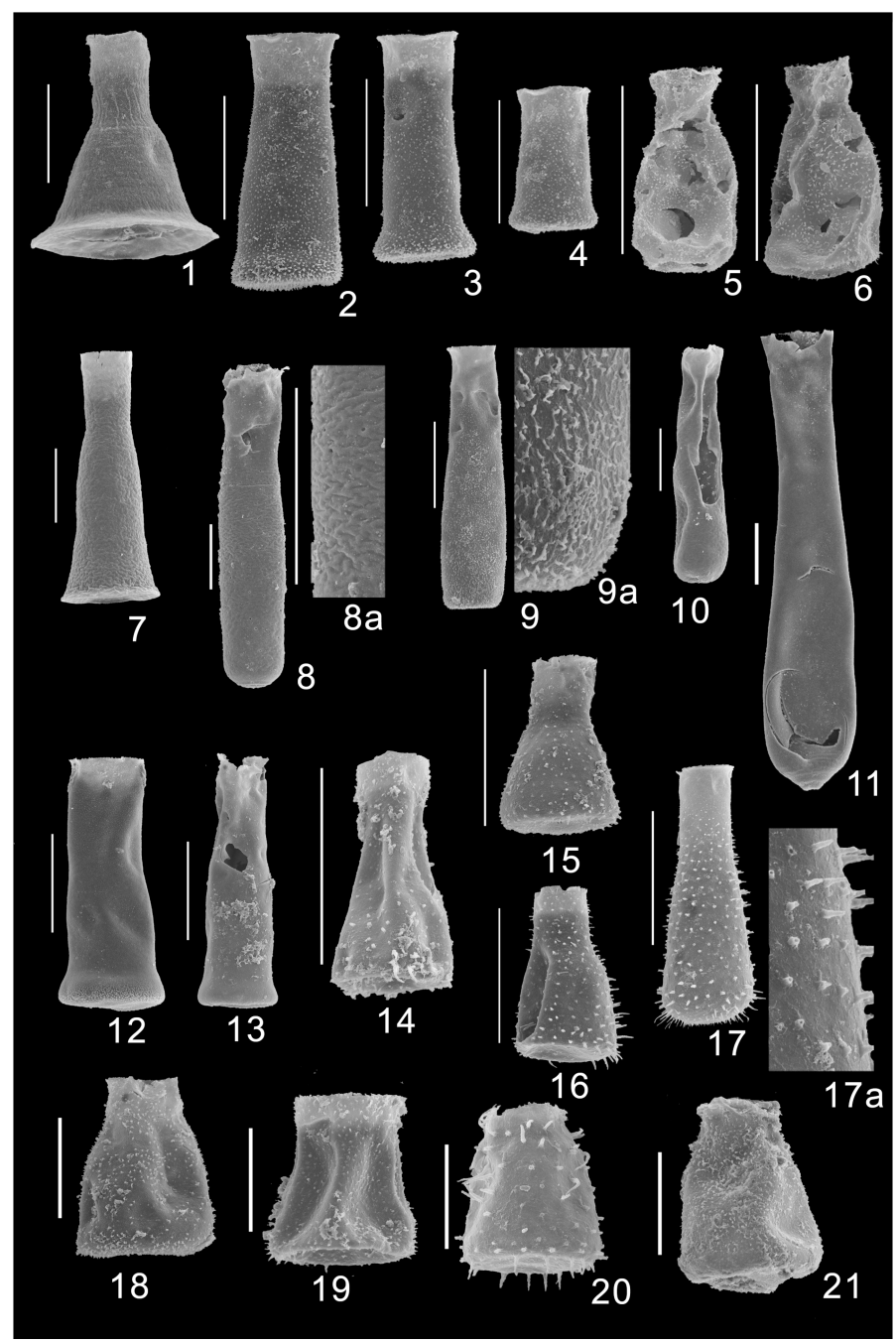

Figure 12 Chitinozoans from the lowermost Viola Springs Formation at Section D. The scale bar is $0.1 \mathrm{~mm}$, except figs 18,19 , 20, 21, where the bar is $0.05 \mathrm{~mm}$. The distribution of specimens is shown in Figure 7. 1 Cyathochitina kuckersiana (Eisenack). 2-4 Belonechitina micracantha (Eisenack). 5-6 ?Belonechitina $s p .7$ Cyathochitina calix (Eisenack). 8 Conochitina tigrina Laufeld. 9 Belonechitina sp. n. A. 10 Conochitina dolosa Laufeld. 11 Conochitina minnesotensis (Stauffer). 12 Belonechitina sp. $n$. B. 13 Pistillachitina $s p$. 14 Spinachitina $c f$. S. cervicornis (Eisenack). 15 Belonechitina sp. n. C. 16 Belonechitina wesenbergensis brevis (Eisenack). 17 Belenochitina wesenbergensis elongata (Eisenack). 18-19 Eisenackitina aff. E. rhenana (Eisenack). 20 Belonechitina cactacea (Eisenack). 21 Belonechitina cf. B. cactacea (Eisenack).

\section{K-bentonites of Section D}

As reported by Leslie et al. (in press), two K-bentonite beds have been positively identified at this section, where they are located 7.4 meters and 11.50 meters, respectively below the top of the Bromide Formation. About 0.6 meters above the upper of these ash beds is a clay bed that might be another K-bentonite although this needs confirmation by geochemical study. Decker (1933) and others have reported the presence of a 3 centimeters thick clay bed at the top of the Bromide Formation but the nature of this shaly bed requires further study. As noted by Leslie et al. (in press), the upper K-bentonite and the overlying clay bed in the Bromide Formation occupy a very similar stratigraphic position as the two upper K-bentonites in the Womble Shale at the GSSP and they may well represent the same ash falls. Further studies are needed to clarify if any of the Section D K-bentonites are identical with the widespread Deicke or Millbrig $\mathrm{K}$-bentonites that are present in the same stratigraphic interval (the

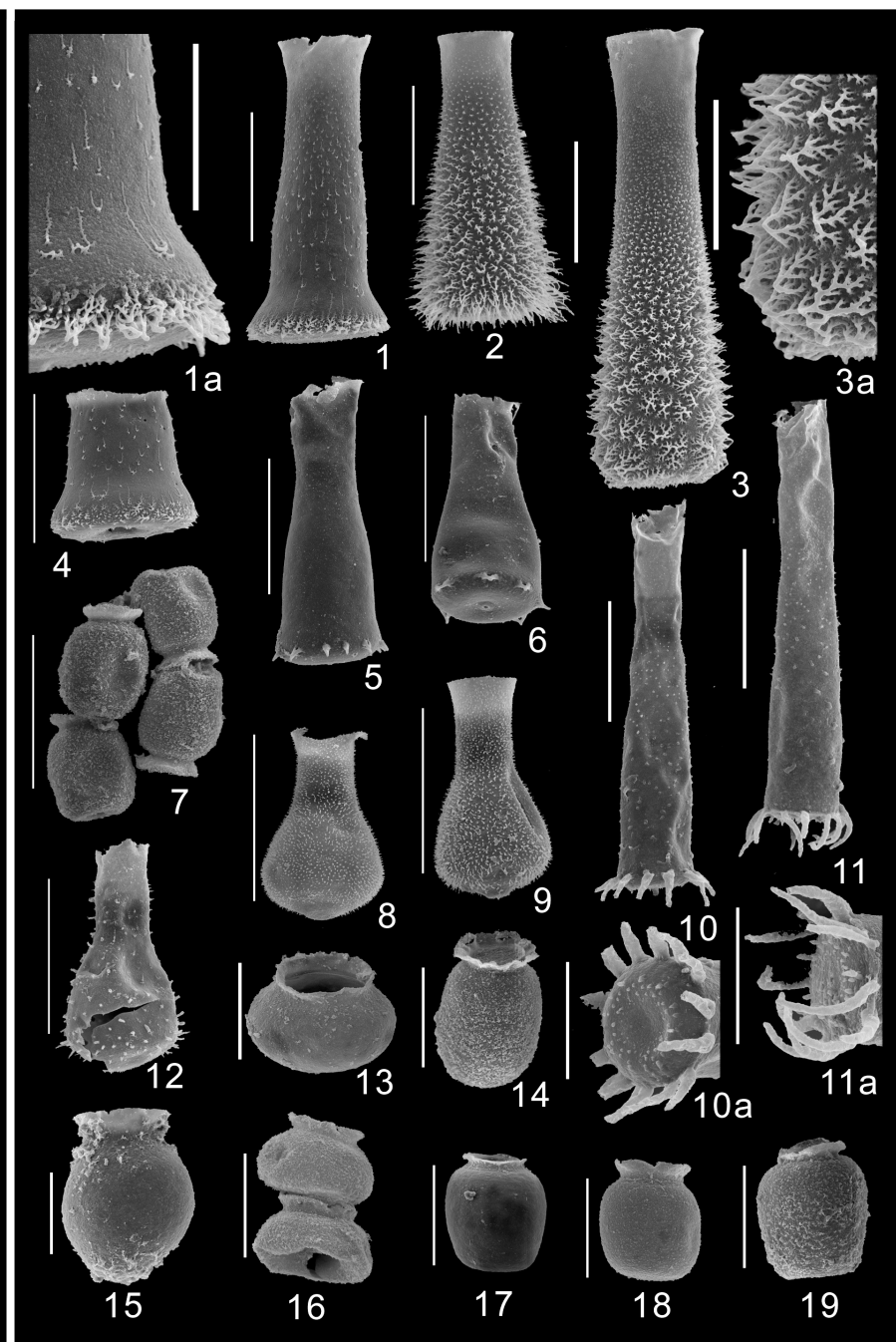

Figure 13 Chitinozoans from the lowermost Viola Springs Formation at Section D. The length of the bar is $0.1 \mathrm{~mm}$, except figs 1a, 3a, 10a, 11a 13, 14, 15, 17, 18, 19, where the bar is $0.05 \mathrm{~mm}$. The distribution of species is shown in Figure 7. 1, 4, Gen. et sp. n. 1 (Clathrochitina ?). 2-3 Belonechitina robusta (Eisenack) s.l. 5-6 Spinachitina alaticornis (Jenkins). 7 Desmochitina minor Eisenack. 8-9 Angochitina sp. n. A. 10-11 Gen. et sp. n. 2 (Spinachitina ?). 12 Angochitina capillata Eisenack. 13, 16 Calpichitina lata (Schallreuter). 14 Desmochitina $c f$. D. ovulum Eisenack. 15 Desmochitina amphorea Eisenack. 17, 18. Desmochitina minor Eisenack. 19 Desmochitina $c f$. D. piriformis Laufeld. 
Phragmodus undatus Zone) over much of the eastern Midcontinent (Kolata et al., 1996).

\section{Global correlation of the base of the Katian Stage of the Upper Ordovician Series}

An examination of other important Upper Ordovician graptolite localities reveals that the FAD of Diplacanthograptus caudatus occurs in a highly consistent position relative to associated taxa (Figure 1), and hence, provides a suitable level for the base of the Katian Stage of the Upper Ordovician Series. As noted earlier, the FAD of D. caudatus occurs in rapid succession with all or a sub-set of the following other graptolite first occurrences - D. lanceolatus, Corynoides americanus, Orthograptus pageanus, O. quadrimucronatus, Dicranograptus hians, and Neurograptus margaritatus. A brief review of the post - C. bicornis graptolite successions at several international key localities is provided below.

\section{Scotland}

The classic graptolite sequence in the Southern Uplands of Scotland has been thoroughly revised by Williams $(1982,1994)$ and Zalasiewicz et al. (1995). D. caudatus appears in rapid succession with D. spiniferus, Neurograptus margaritatus, Orthograptus quadrimucronatus, O. pageanus and Dicranograptus clingani. Zalasiewicz et al. (1995) placed the base of their clingani Zone at the FAD of D. caudatus and sub-divided the zone into a caudatus Subzone and a morrisi Subzone for correlation purposes. They also noted that the overlying Pleurograptus linearis Zone is best recognized not by the nominal species, which is restricted to very few horizons and it is difficult to identify in fragmentary material, but by the presence of Climacograptus styloideus and Climacograptus tubuliferus.

The section at Hartfell Score (Zalasiewicz et al., 1995) is the only one we know in which $D$. spiniferus appears coincident with $D$. caudatus as opposed to occurring higher stratigraphically (as at Dobb's Linn, see Williams, 1994). It is also worth noting that 1.5 to 2.0 meters of barren gray shale separate the underlying wilsoni Zone from the clingani Zone at Hartfell (Zalasiewicz et al., 1995, fig. 2). Although the FAD of D. spiniferus at Hartfell Score is anomalously low, the FAD of $D$. caudatus is consistent in its position relative to other key index taxa (see Figure 1).

\section{Australasia}

In Australia, D. caudatus appears with $N$. margaritatus just below the base of Eastonian 1 (Ea1), which corresponds to the Diplacanthograptus lanceolatus Zone. Thus, the base of the Katian Stage of the Upper Ordovician correlates with a level near the top of Gisbornian 2 in the Australasian sequence. Ea1 is characterized by the appearance of D. lanceolatus, Corynoides americanus, Orthograptus pageanus, Dicranograptus hians, and O. quadrimucronatus (VandenBerg and Cooper, 1992). The D. lanceolatus Zone is succeeded by the Diplacanthograptus spiniferus Zone (Ea2), and the Dicranograptus kirki Zone (Ea3).

\section{Newfoundland}

Ordovician graptolites from the Lawrence Harbour Formation in north-central Newfoundland have been described by Erdtmann (1976) and Williams (1995). The graptolite succession is most similar to that of Australia, although Williams (1995) adopted the British zonal scheme (see Figures 1 and 2). It is important to note that while Williams used the Scottish zonation, he recognized the D. clingani Zone based primarily on the presence of $D$. caudatus, D. lanceolatus and D. spiniferus, and the P. linearis Zone was identified on the occurrence of Climacograptus tubuliferus.

\section{Kalpin, Xinjiang, China}

Chen et al. (2000) provided a detailed graptolite range chart from the Qilang and Yingan formations in the Dawangou section, Kalpin, in western Xinjiang. D. caudatus appears with D. lanceolatus, and O. quadrimucronatus in the lowermost Yingan Formation (Chen et al., 2000, fig. 3) suggesting a precise correlation with the base of the Katian Stage at Black Knob Ridge.

\section{Eastern North America}

The classical New York State-Quebec graptolite sequence described by Ruedemann $(1908,1912,1925)$ and Riva $(1969,1974)$ contains one of the best known and most provincial faunas in post- $C$. bicornis Zone rocks. Riva's $(1969,1974)$ C. americanus Zone can be correlated with the successions at Black Knob Ridge and other regions by the presence of $D$. caudatus, $C$. americanus, $O$. pageanus, and $O$. quadrimucronatus. Above the $C$. americanus Zone, faunas in eastern North America become increasingly endemic and difficult to correlate (Riva, 1974; Goldman et al., 1995).

\section{Scandinavia}

Diplacanthograptus caudatus is rare in the Upper Ordovician rocks of Scandinavia. Graptolite faunas in post-C. bicornis age rocks are generally of low diversity and contain numerous endemic species (Hadding, 1915; Nilsson, 1977; Williams and Bruton, 1993; Pålsson, 2001). However, based on identifications by O.M.B. Bulman, Thorslund (1940) reported D. caudatus in association with Dicranograptus clingani, Dicellograptus pumilus, Corynoides sp., Archiclimacograptus compactus, Amplexograptus vasae, Normalograptus brevis, $N$. pulchellus, $C$. rugosus, Orthograptus calcaratus vulgatus, Rectograptus pauperatus, and Neurograptus margaritatus from the Örå Shale in the Province of Jämtland. This fauna indicates a $D$. clingani Zone age and suggests a correlation with the D. caudatus Zone.

Hadding (1913), Nilsson (1977), and others have reported specimens of " $C$. caudatus" from much older strata $(H$. teretiusculus Zone) in Scania, southern Sweden. Hadding (1913) noted that the Swedish specimens were similar to, but smaller than, specimens from Great Britain and North America. According to unpublished studies by D.G., the Scanian specimens belongs to Archiclimacograptus sheldoni Hughes.

\section{Conclusions}

The Black Knob Ridge Section contains an excellent record of the Climacograptus bicornis-Diplacanthograptus caudatus zonal boundary, the level that was chosen by the International Subcommission on Ordovician stratigraphy as the base of the Katian Stage of the Upper Ordovician Series. The boundary interval is abundantly fossiliferous, and the FAD of D. caudatus has been precisely located at four meters above the base of the Bigfork Chert. The first appearance of D. caudatus occurs within a succession of other graptolite first occurrences, including Corynoides americanus, Dicranograptus hians, Orthograptus quadrimucronatus, O. pageanus, and Neurograptus margaritatus, which are remarkably consistent worldwide. Additionally, the shales above and below the graptolite zonal boundary contain biostratigraphically important conodonts and chitinozoans. Based on graptolites, conodonts and chitinozoans, the GSSP succession can be correlated closely with sequences in nearby sections of the Viola Springs Formation that contain a more complete succession of conodont species and are part of Sweet's (1979, 1984, 1995) graphic correlation framework. Thus, the biostratigraphic level of the base of the D. caudatus Zone (and hence the base 
of the Katian Stage) can be precisely correlated into both graptolitic shale and shallower-water platform carbonate sections. Finally, the GSSP section is well exposed, easily accessible, and the biostratigraphy can be independently tested with carbon isotope chemostratigraphy.

\section{Acknowledgments}

This work was supported by National Science Foundation grant EAR - 0106844 to D. Goldman and Estonian Science Foundation grant ETF - 5922 to J. Nõlvak. We would like to thank S.C. Finney for showing us the Black Knob Ridge section, suggesting its potential as a GSSP, and critically reviewing previous versions of the manuscript.

\section{References}

Alberstadt, L.P., 1973, Articulate brachiopods of the Viola Formation (Ordovician) in the Arbuckle Mountains, Oklahoma: Oklahoma Geological Survey Bulletin 117, 90 pp.

Bergström, S. M., 1971, Conodont biostratigraphy of the Middle and Upper Ordovician of Europe and Eastern North America: Geological Society of America Memoir 127, pp. 83-157.

Bergström, S. M., 1978, Middle and Upper Ordovician conodont and graptolite biostratigraphy of the Marathon, Texas graptolite zone reference standard: Palaeontology, v. 21, pp. 723-758.

Bergström, S. M., 1986, Biostratigraphic integration of Ordovician graptolite and conodont zones - a regional review. In C.P. Hughes and R.B. Rickards, eds., Paleoecology and Biostratigraphy of Graptolites: Geological Society Special Publication No. 20, pp. 61-78.

Bergström, S. M., Finney, S.C., Chen Xu, Pålsson, C., Wang Zhi-hao, and Grahn, Y., 2000, A proposed global boundary stratotype for the base of the Upper Series of the Ordovician System: the Fågelsång section, Scania, southern Sweden: Episodes, v. 23, pp. 102-109.

Bergström, S. M., Finney, S. C., Chen, Xu, Goldman, D., and Lesliem, S. A., 2006. Three new Ordovician global stage names. Lethaia v. 39, pp. 287-288.

Berry, W.B.N., 1970, Review of late Middle Ordovician graptolites in eastern New York and Pennsylvania: American Journal of Science, v. 269, pp. 304-313.

Berry, W.B.N., 1977, Ecology and age of graptolites from graywackes in eastern New York: Journal of Paleontology, v. 51, pp. 1102-1107.

Bradshaw, L.E., 1974, Ordovician conodonts from Black Knob Ridge, Oklahoma: Geological Society of America, Abstracts with Programs, v. 6, p. 494.

Chen Xu, Ni Yu-Nan, Michell, C.E., Qiao Xin-Dong, and Zhan Shi-Gao, 2000, Graptolites from the Quilang and Yingan formations (Caradoc, Ordovician) of Kalpin, Western Tarim, Xinjiang, China: Journal of Paleontology, v. 74, pp. 282-300.

Decker, C.E., 1935, Graptolites of the Sylvan Shale of Oklahoma and the Polk Creek Shale of Arkansas: Journal of Paleontology, v. 9, pp. 697-708.

Dworian, P.R., 1990, The biostratigraphy and biogeography of Upper Ordovician graptolites from North America: Unpublished Master of Science Thesis, California State University, Long Beach.

Ethington, R.L., Finney, S.C., and Repetski, J.E., 1989, Biostratigraphy of the Paleozoic rocks of the Ouachita Orogen, Arkansas, Oklahoma, West Texas. In R.D. Hatcher, Jr., W.A. Thomas, and G.W. Viele, eds., The Geology of North America, v. F-2, The Appalachian-Ouachita Orogen in the United States, pp. 563-573. Geological Society of America, Denver.

Finney, S.C., 1986, Graptolite biofacies and correlation of eustatic, subsidence, and tectonic events in the Middle to Upper Ordovician of North America: Palaios, v. 1, pp. 435-461.

Finney, S.C., 1988, Middle Ordovician strata of the Arbuckle and Ouachita Mountains, Oklahoma: Contrasting lithofacies and biofacies deposited in southern Oklahoma Aulacogen and Ouachita Geosyncline. In O.T. Heyward, ed., Geological Society of America Centennial Field Guide South-Central Section, pp. 171-176. Geological Society of America, Denver.

Finney, S.C., 2005, Global Series and Stages for the Ordovician System: A progress report: Geologica Acta, v. 3, pp. 309-316.

Finney, S.C., and Bergström, S.M., 1986, Biostratigraphy of the Ordovician Nemagraptus gracilis Zone. In C.P. Hughes and R.B. Rickards, eds.,
Paleoecology and biostratigraphy of graptolites: Geological Society Special Publication 20, pp. 47-59.

Goldman, D., 2003, The Diplacanthograptus caudatus Zone: a proposal for a new, globally recognizable, Upper Ordovician graptolite zone. In G.L. Albanesi, M.S. Beresi, and S.H. Peralta, eds., Ordovician From The Andes: Instituto Superior de Correlación Geológica (INSUGEO), Serie Correlación Geológica, no. 17, pp. 65-70.

Goldman, D., and Wright, S.J., 2003, A revision of "Climacograptus caudatus" (Lapworth) based on isolated three-dimensional material from the Viola Springs Formation of Central Oklahoma, USA. In G. Ortega, and G.F. Aceñolaza, eds., Proceedings of the 7th International Graptolite Conference: Instituto Superior de Correlación Geológica (INSUGEO), Serie Correlación Geológica, no. 18, pp. 33-37.

Goldman, D., Mitchell, C.E., Bergström, S.M., Delano, J.W., and Tice, S., 1994, K-bentonites and graptolite biostratigraphy in the Middle Ordovician of New York State and Quebec: A new chronostratigraphic model: Palaios, v. 9, pp. 124-143.

Goldman, D., Bergström, S.M., and Mitchell, C.E., 1995, Revision of the Zone 13 graptolite biostratigraphy in the Marathon, Texas, standard succession and its bearing on Upper Ordovician graptolite biogeography: Lethaia, v. 28, pp. 115-128.

Goldman, D., Mitchell, C.E., and Joy, M.P., 1999, The stratigraphic distribution of graptolites in the classic Middle Ordovician Utica Shale of New York State: an evolutionary succession or a response to relative sea-level change?: Paleobiology, v. 25, pp. 273-294.

Goldman, D., Janousek, H.M., Mitchell, C.E., and Maletz, J., 2002, Paleogeographic, Paleoceanographic, and Tectonic Controls on Early Late Ordovician Graptolite Diversity Patterns: Geological Society of America Abstracts with Programs, v. 34(6), p. 315.

Grahn, Y. and Miller, M.A., 1986, Chitinozoa from the Middle Ordovician Bromide Formation, Arbuckle Mountains, Oklahoma, U.S.A: Neues Jahrbusch für Geologie und Paläontologie, Abhandlungen., v. 172, pp. 381-403.

Gurley, R.R., 1892a, The geologic age of the graptolite shales of Arkansas: Arkansas Geological Survey Annual Report, v. 3, pp. 401-404.

Gurley, R.R., 1892b, New Species of graptolites: Arkansas Geological Survey Annual Report, v. 3, pp. 416-418.

Hadding, A., 1913, Undre Dicellograptusskiffern i Skåne: Lunds Universitets Årsskrift, N.F. 2, v. 9, pp. 1-92.

Hadding, A., 1915, Der Mittlere Dicellograptusschiefer auf Bornholm: Lunds Universitets Årsskrift, N.F. 2, v. 11, pp. 1-39.

Harlton, B.H., 1953, Ouachita chert facies, southeastern Oklahoma: Bulletin of the American Association of Petroleum Geologists, v. 37, pp. 778-796.

Haynes, J.T., Melson, W.G., and Kunk, M.J., 1996, Composition of biotite phenocrysts in Ordovician tephras casts doubts on the proposed transAtlantic correlation of the Millbrig (United States) and the Kinnekulle Kbentonite (Sweden): Geology, v. 23, pp. 847-850.

Hendricks, T.A., Knechtel, M.M., and Bridge, J., 1937, Geology of Black Knob Ridge, Oklahoma: Bulletin of the American Association of Petroleum Geologists, v. 21, pp. 1-29.

Holland, S.M., and Patzkowsky, M.E., 1996, Sequence stratigraphy and long-term paleoceanographic changes in the Middle and Upper Ordovician of the eastern United States. In B.J. Witzke, G.A. Ludvigson, and J.E. Day, eds., Paleozoic sequence stratigraphy: Views from the North American craton: Geological Ssociety of America Special Paper 306, pp. $117-128$.

Jenkins, W.A.M., 1969, Chitinozoa from the Ordovician Viola and Fernvale Limestones of the Arbuckle Mountains, Oklahoma: Special Papers in Palaeontology, v. 5, pp. 1-44.

Kolata, D.R., Huff, W.D., and Bergström, S.M., 1996, Ordovician K-bentonites of eastern North America: Geological Society of America Special Paper 313, pp. 1-90.

Krueger, D., 2002, Conodont Biostratigraphy of Middle and Upper Ordovician rocks in the Ouachita Mountains of Arkansas and Oklahoma: Unpublished PhD dissertation, University of Missouri-Columbia, $279 \mathrm{pp}$.

Leslie, S.A., Bergström, S.M., Huff, W.D., and Sell, B.K., in press, Ordovician K-bentonites discovered in Oklahoma: Oklahoma Geology Notes.

Leslie, S. A., Bergstrom, S. M., and Huff, W. D., 2006: Volcanic ash beds discovered in the upper Bromide Formation and Womble Shale (Ordovician) in Oklahoma: The westernmost occurrences of the Millbrig and Deicke K-bentonites? Geological Society of America Abstracts with Programs, v. 38(1), p. 31.

Leslie, S.A., Goldman, D., Young, S.A., Saltzman, M.R., and Nõlvak, J., 2004, The Black Knob Ridge Section, Southeastern Oklahoma, USA: A Possible Global Stratotype-Section and Point (GSSP) for the Base of the Diplacanthograptus caudatus Biozone and the Middle Stage of the 
Upper Ordovician Series: Geological Society of America, Abstracts with Programs, v. 36(5), p. 75.

Miser, H.D., and Purdue, A.H., 1929, Geology of the De Queen and Caddo Gap Quadrangles, Arkansas: United States Geological Survey Bulletin 808, 195 pp.

Nilsson, R., 1977, A boring through Middle and Upper Ordovician strata at Koängen in western Scania, southern Sweden: Sveriges Geologiska Undersökning, C733, pp. 1-58.

Nõlvak, J. and Grahn, Y., 1993, Ordovician chitinozoan zones from Baltoscandia: Review of Palaeobotany and Palynology, v. 79, pp. 245-269.

Oberg, R., 1966, The conodont fauna of the Viola Formation: Unpublished $\mathrm{PhD}$ dissertation, University of Iowa, $186 \mathrm{p}$.

Pålsson, C., 2001, Graptolites from the Upper Ordovician Dicranograptus clingani Zone at Järrestad, Scania, southern Sweden: GFF, v. 123, pp. 217-224.

Paris, F., 1990, The Ordovician chitinozoan biozones from the North Gondwana domain: Reviews of Palaeobotany and Palynology, v. 66, pp. 181-209.

Patzkowsky, M.E., Slupik, L.M., Arthur, M.A., Pancost, R.D., and Freeman, K.H., 1997, Late Middle Ordovician environmental change and extinction: Harbinger of the Late Ordovician or a continuation of Cambrian patterns?: Geology, v. 25, pp. 911-914.

Repetski, J.E., and Ethington, R.L., 1977, Conodonts from the graptolite facies in the Ouachita Mountains, Arkansas and Oklahoma. In C.G. Stone, ed., Symposium on the Geology of the Ouachita Mountains: Arkansas Geological Commission, v. 1, pp. 92-106.

Riva, J., 1969, Middle and Upper Ordovician graptolite faunas of St. Lawrence Lowlands of Quebec, and of Anticosti Island. In M. Kay, ed. North Atlantic - geology and continental drift. A symposium: American Association of Petroleum Geologists Memoir 112, pp. 579-595.

Ruedemann, R., 1908, Graptolites of New York, Part II: Graptolites of Higher Beds: New York State Museum Memoir 11, pp. 487-583.

Ruedemann, R., 1947, Graptolites of North America: Geological Society of America Memoir 19, 652 p.

Sweet, W.C., 1979, Late Ordovician conodonts and biostratigraphy of the western Midcontinent Province: Brigham Young University Geology Studies, v. 26(3), pp. 45-88

Sweet, W.C., 1983, Part II-Conodont Biostratigraphy of the Fite Formation and Viola Group. In T.A. Amsden, and W.C. Sweet, Upper Bromide and Viola Group (Middle and Upper Ordovician) in eastern Oklahoma: Oklahoma Geological Survey Bulletin 132, pp. 23-51.

Sweet, W.C., 1984, Graphic correlation of upper Middle and Upper Ordovician rocks, North American Midcontinent Province, USA. In D.L. Bruton, ed., Aspects of the Ordovician System: Palaeontological Contributions from the University of Oslo, No. 295, pp. 23-35.

Sweet, W.C., 1995, Graphic assembly of a conodont-based composite standard for the Ordovician System of North America. In K.O. Mann, and H.R. Lane, eds., Graphic Correlation: SEPM Society for Sedimentary Geology Special Publication, No. 53, pp. 139-150.

Thorslund, P. 1940. On the Chasmops Series of Jemtland and Södermanland (Tvären): Sveriges Geologiska Undersökning, C 436, pp. 1-191

Ulrich, E.O., 1911, Revision of the Paleozoic Systems: Geological Society of America Bulletin, v. 22, pp. 281-680.

Vandenberg, A.H.M., 1990, The ancestry of Climacograptus spiniferus Ruedemann: Alcheringa, v. 14, pp. 39-51.

Vandenberg, A.H.M., and Cooper, R.A., 1992, The Ordovician graptolite sequence of Australasia: Alcheringa, v. 16, pp. 33-85.

Webby, B.D., Cooper, R.A., Bergström, S.M., and Paris, F., 2004, Stratigraphic Framework and Time Slices. In B.D. Webby, F. Paris, M.L. Droser, and I.G. Percival, eds., The Great Ordovician Biodiversification Event, pp. 41-47, Columbia University Press, New York.

Williams, S.H., 1982, Upper Ordovician graptolites from the top Lower Hartfell Shale Formation (D. clingani and P. linearis zones) near Moffat, southern Scotland: Transactions of the Royal Society of Edinburgh, Earth Sciences, v. 72, pp. 229-255.

Williams, S.H., 1995, Middle Ordovician Graptolites from the Lawrence Harbour Formation, Central Newfoundland, Canada: Palaeontographica, Abt. A, v. 235, pp. 21-77.

Williams, S.H., and Bruton, D.L., 1983, The Caradoc-Ashgill boundary in the central Oslo Region and associated graptolite faunas: Norsk Geologisk Tidsskrift, v. 63, pp. 147-191.

Young, S.A., Saltzman, M.R., Bergström, S.M., Holmden, C., and Patterson, W. 2003. Paleoceanographic aspects of the Early Chatfieldian (Upper Middle Ordovician) positive $\delta^{13} \mathrm{C}$ excursion (GICE): Geological Society of America, Abstracts with Programs, v. 35(6), p. 315.

Young, S.A., Saltzman, M.R., and Bergström, S.M., 2005, Upper Ordovician (Mohawkian) carbon isotope $\left(\delta^{13} \mathrm{C}\right)$ stratigraphy in eastern and central
North America: Regional expression of a perturbation of the global carbon cycle: Palaeogeography, Palaeoclimatology, Palaeoecology, v. 222, pp. 53-76.

Zalasiewicz, J., Rushton, A.W.A., and Owen, A.W., 1995, Late Caradoc graptolitic faunal gradients across the Iapetus Ocean: Geological Magazine, v. 132, pp. 611-617.

Daniel Goldman is an Associate Professor in the Department of Geology at the University of Dayton, Ohio, U.S.A., where he has been teaching since 1997 after completing post-doctoral research appointments at the University at Buffalo and the Ohio State University. His principal research interests are evolutionary trends and biodiversity dynamics in Ordovician graptolites, quantitative biostratigraphy, and Lower Paleozoic biogeography.

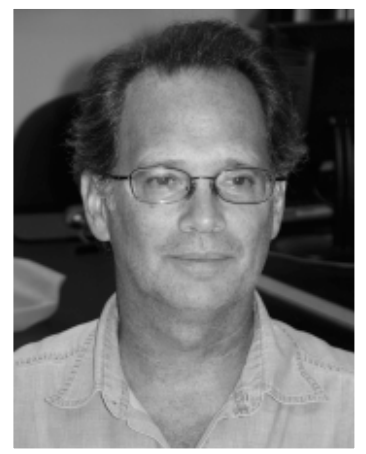

Stephen A. Leslie is Professor and Department Head of Geology and Environmental Science at James Madison University in Harrisonburg, Virginia, U.S.A. His interests include Ordovician stratigraphy, the taphonomy of exceptionally preserved fossils, and how naturally occurring radiation has affected evolution through deep time. Most of his research has focused on Ordovician conodont paleontology, the isotopic record within conodonts, and integrating sequence stratigraphy with conodont biostratigraphy to predict the distribution of bedding plane occurrences of conodonts in siliciclastic-dominated sequences.

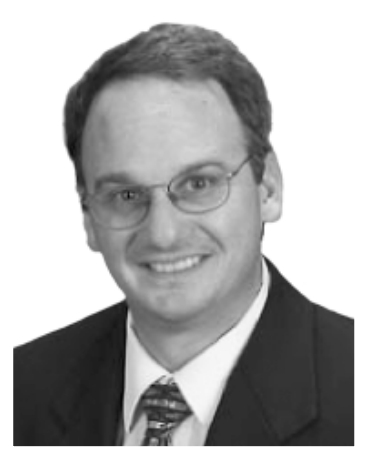

Jaak Nõlvak, born in June of 1944, is a senior researcher at the Institute of Geology at Tallinn University of Technology. He received his professional education at Tartu University, and his $P h D$ in natural sciences (2002) from Tallinn Technical University. He is a member of the Estonian Stratigraphic Commission and his main research interests are the Ordovician biostratigraphy of Baltoscandia, and chitinozoan systematics and distribution.

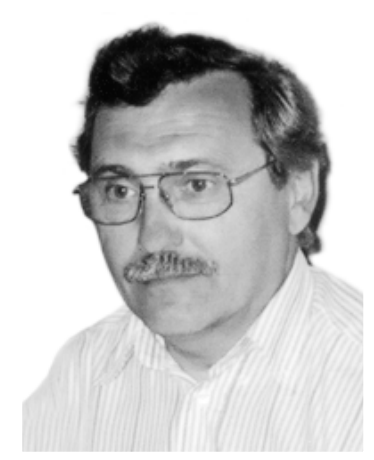

